\title{
Biodegradation and detoxification of phenanthrene in in- vitro and in-vivo conditions by a newly isolated ligninolytic fungus Coriolopsis byrsina strain APC5 and characterization of their metabolites for environmental safety
}

Nikki Agrawal

Guru Ghasidas Vishwavidyalaya: Guru Ghasidas University

Vineet Kumar

Guru Ghasidas Vishwavidyalaya: Guru Ghasidas University

Sushil Kumar Shahi ( $\nabla$ sushilkshahi@gmail.com )

Guru Ghasidas Vishwavidyalaya: Guru Ghasidas University

\section{Research Article}

Keywords: Coriolopsis byrsina strain APC5, Ligninolytic enzymes, PHE degradation, HPLC, GC-MS, Phytotoxicity

Posted Date: March 30th, 2021

DOI: https://doi.org/10.21203/rs.3.rs-326028/v1

License: (c) (i) This work is licensed under a Creative Commons Attribution 4.0 International License. Read Full License

Version of Record: A version of this preprint was published at Environmental Science and Pollution Research on July 6th, 2021. See the published version at https://doi.org/10.1007/s11356-021-15271-w. 


\section{Abstract}

Polycyclic aromatic hydrocarbons (PAHs) are recalcitrant organic pollutants generated from agricultural, industrial, and municipal sources, and their strong toxic, carcinogenic and teratogenic properties pose a harmful threat to human beings. The present study delas with the bioremediation of phenanthrene by a ligninolytic fungus, Coriolopsis byrsina strain APC5, isolated from the fruiting body of decayed wood surface. During the experiment, Coriolopsis byrsina strain APC5 was found as a promising organisms for the degradation and detoxification of phenanthrene (PHE) in in-vitro and in-vivo conditions. HPLC analysis showed that the C. byrsina strain degraded $99.90 \%$ of $20 \mathrm{mg} / \mathrm{L}$ PHE in in-vitro condition wheras $77.48 \%$ degradation of $50 \mathrm{mg} / \mathrm{L}$ PHE was reported in in-vivo condition. The maximum degradation of PHE was noted at $\mathrm{pH} 6.0$ at $25^{\circ} \mathrm{C}$ temperature under shaking flask conditions. Further GCMS analysis of fungal treated samples showed detection of 9, 10-Dihydroxy phenanthrene, 2, 2-Diphenic acid, phthalic acid, 4-heptyloxy phenol, benzene octyl and acetic acid anhydride as a metabolic products of degraded PHE. Furthermore, the phytotoxicity evaluation of degraded PHE was observed through the seed germination method using Vigna radiata and Cicer arietinum seeds. The phytotoxicity results showed that the seed germination index and vegetative growth parameters of plants were increased in the degraded PHE soil. As a result, $C$. byrsina strain APC5 was found to be a potential organism for the degradation and detoxification of PHE without showing any adverse effect of their metabolites.

\section{Introduction}

Polycyclic aromatic hydrocarbons (PAHs) are major environmental concern organic pollutants with toxic, mutagenic and carcinogenic properties to human and animals (Abdel-shafy and Mansour, 2015; Ainerua et al., 2021; Idowu et al., 2019). Atmospheric PAHs are released into soils, water, sediments, and vegetation through incomplete combustion, oil spills, incineration processes, forest fires, volcanic eruptions, and vehicular exhausts, by the transformation of PAHs via biological process and abiotic reactions (Bandowe et al., 2019; Ghosal et al., 2016; Xu et al., 2021). The United States Environment Protection Agency (USEPA) and European Commission (EC) have identified 16 PAHs compunds as priority pollutants including phenanthrene (PHE) on the basis of their toxicity (Kalugina et al., 2018; Wu et al., 2016). PHE is found most abundantly in the aquatic environment, including tap water, surface water, and wastewater; it has also been recognized in the sea food collected from contaminated water (IARC, 1983; USEPA, 1988). It is considered by scientific community as a model compound for the PAHs degradation study because it contains K-region and bay-region in their structure, which are found in the structure of higher molecular weight PAHs (Garcia-uitz et al., 2016; Luo et al., 2020). Due to the presenence of K-region and bay-region in their structure, PHE is structurally stable and recalcitrant in nature. PHE showed toxic effect on the human respiratory system and caused photosensitization of the skin (Budavari et al., 1989; Xu et al., 2006), therefore, globally it is necessary to the remediation of PAHs from the environment.

A wide array of various physical, chemical, and biological methods has been applied for the degradation and remeidiation of PAHs from the contaminated environment. The physico-chemical method includes incineration, photodegradation (Nguyen et al., 2020), nano-filtration (Li et al., 2019), electrokinetic remediation (Pourfadakari et al., 2020), thermal desorption (Falciglia et al., 2020; Li et al., 2020), soil washing (Gitipour et al., 2018), radiocolloid treatment, electron beam irradiation (Xu et al., 2020), and chemical immobilization has been found efficient for degradation of PAHs. However these methods of remediation are expensive, in many cases they only transfer the toxic compounds from one phase to another phase and cause a secondary pollution and unable to degrade high molecular weight (HMW) PAHs (Antosova et al., 2020; Li et al., 2014). Thus, cost effective, efficient, and sustainable biological method involving microorganisms for the degradation of PAHs have been developed (Zhao et al., 2009). 
Bioremediation has gained much attention in recent past for the remediation of hazardous and toxic environmental pollutants from contaminated sites (Asgher et al., 2008; Haritash and Kaushik, 2009; Romantschuk et al., 2002). Various microbes such as bacterial species, Pseudomonas aeruginosa PFL-P1 (Mahto and Das, 2020), Paracoccus aminovorans HPD-2 (Teng et al., 2010), Burkholderia cepacia (Chen et al., 2013), Roseobacter clade (Zhou et al., 2020) Sphingomonas sp. GY2B (Liu et al., 2017) and fungal species, Trametes hirsuta D7 (Hidayat and Yanto, 2018), Ganoderma lucidum (Agrawal et al., 2018), Pleurotus ostreatus (Pozdnyakova et al., 2018), Leucoagaricus gongylophorus (Ike et al., 2019), and Armillaria sp. FO22 (Hadibarata and Kristanti, 2012) have been reported for the remediation of PAHs contaminated soil, however as compared with bacteria, fungi is a promising alternative for the remediation of PAHs. Bacteria are able to degrade maximum four ring containing PAHs and secretes intracellular substrate specific enzymes, fungi secreted non-specific, non-selective ligninolytic enzymes viz., lignin peroxidase (LiP), manganese peroxidase (MnP), and laccase (LAC) that are associated with ligninolytic activities., other than this fungi degrade more than four ring containing HMW PAHs. Fungi secretes extracellular broad substrate specific ligninolytic enzymes which penetrate the polluted soil, sludge or matrix and then remove the pollutants, they involves less energy, time, and chemicals and grow on a broad range of substrates (Balaji and Ebenezer, 2008; Bankole et al., 2021; Czaplicki et al., 2018). However, white rot fungi are considered as the most favourable fungi for the investigation of PAHs degradation and their efficiency depends on the microbial strain and the structure of organic pollutants (Agrawal and Shahi, 2017; Jia et al., 2019; Llorens-Blanch et al., 2018). White rot LAC belongs to the multicopper containing phenol oxidase (EC 1.10.3.2: benzenediol, oxygen oxidoreductase or p-diphenol oxidase), which catalyze the oxidation of aromatic ring containing phenols, polyphenols, and non-aromatic substrates through the radical catalyzed mechanism (Moon et al., 2018; Shafiei et al., 2019; Wulandari et al., 2021), LiP (EC 1.11.1.14, 1, 2-bis (3, 4-dimethoxyphenyl) propane-1, 3-diol: hydrogen-peroxide oxidoreductase) catalyze the hydrogen peroxidase dependent cleavage of $\mathrm{Ca}-\mathrm{C}_{\beta}$ and aryl $\mathrm{Ca}$ bond, oxidize phenolic and non-phenolic lignin model compounds (Biko et al., 2020; Naghdi et al., 2018). MnP (EC 1.11.1.13; Mn (II) hydrogen-peroxide oxidoreductase) catalyze the manganese $(\mathrm{Mn})$ dependent oxidation of phenolic compounds in presence of hydrogen peroxide (Emami et al., 2020; Nowak et al., 2020; Wong, 2009). The rate of the PAHs degradation depends on the culture conditions like $\mathrm{pH}$, temperature, oxygen, concentration of PAHs, accessibility of nutrients and agitated culture (Kadri et al., 2017; Ting et al., 2011). Several authors have been reported the degradation of PHE by white rot fungi such as Polyporus sp. S133 (Hadibarata and Tachibana, 2010), Pleurotus eryngii (Wu et al., 2016), P. ostreatus D1 (Pozdnyakova et al., 2018). However, few reports are available on the in-vitro and in-vivo degradation and detoxification of PHE by white rot fungi.

In the present study, PHE degradation by Coriolopsis byrsina strain APC5 was assessed in the in-vitro and in-vivo conditions. Further, degradation of PHE was evaluated by HPLC, FT-IR and GC-MS techniques. Furthermore, ligninolytic enzyme activity and PHE degradation were optimized under different concentration of PHE and physical parameters like $\mathrm{pH}$, temperature, salinity condition. After that formulation of $C$. byrsina fungus was prepared in different substrate to check the PHE degradation efficiency of fungus in-vivo condition. The phytotoxicity of PHE metabolites on the growth of Vigna radiata and Cicer arietinum was also investigated.

\section{Material And Methods}

\subsection{Chemicals and reagents}

All the chemicals, solvents and reagents were used in the present investigation, were of analytical grade and used without further purification. PHE (>98.0\% analytical standard), Sabouraud dextrose agar (SDA), Azure B, guaiacol, 2, 6-dimethoxy phenol, and ethyl acetate (HPLC grade) were purchased fromMerck Life Science, Mumbai, India. Bovine serum albumin (BSA) used as a protein standard was supplied from Sigma-Aldrich Chemical Co. Ltd. (St. Louis, 
USA). All the starad media and working solutions were prepared by using ultrapure water generated by the Milli-Q system (ELIX, Merck Millipore, India)

\subsection{Fungi culture and medium for PHE degrdation}

C. byrsina strain APC5 (KY418163.1) isolated from the fruiting body of decayed wood surface in our laboratory, was used for the investigation of PHE degradation (Agrawal and Shahi, 2017). Sabouraud dextrose agar (SDA) medium containing seven days old culture of strain APC5 (one disc of $8 \mathrm{~mm}$ diameter) was used as the inoculum for the degradation and enzyme analysis. The Mineral salt broth (MSB) medium used for PHE degradation and ligninolytic enzyme activity investigation was contains (g/L): Glucose - 10, $\mathrm{KH}_{2} \mathrm{PO}_{4}-2.0, \mathrm{MgSO}_{4} .7 \mathrm{H}_{2} \mathrm{O}-0.5, \mathrm{CaCl}_{2} .2 \mathrm{H}_{2} \mathrm{O}-0.1$, Ammonium tartrate -0.2 , trace element solution - $10(\mathrm{~mL})$ (Arora and Gill, 2001). MSB medium was supplemented with antibacterial compound (to inhibit the bacterial growth) and $0.45 \mu \mathrm{m}$ membrane filter sterilize $20 \mathrm{mg} / \mathrm{L}$ concentration of PHE. The pH of the MSB medium was adjusted to 7.0 with the help of $0.1 \mathrm{~N} \mathrm{NaOH}$ or $0.1 \mathrm{~N} \mathrm{HCl}$.

\subsection{Analysis of PHE degradation by plate assay}

Preliminary Bushnell Haas Agar (BHA) medium (composition, g/L: $\mathrm{MgSO}_{4}(0.2), \mathrm{CaCl}_{2}(0.02), \mathrm{KH}_{2} \mathrm{PO}_{4}(1), \mathrm{K}_{2} \mathrm{HPO}_{4}$ (1.0), $\mathrm{NH}_{4} \mathrm{NO}_{3}$ (1.0), $\mathrm{FeCl}_{3}$ (0.05), agar (20) supplimented with $20 \mathrm{mg} / \mathrm{L} \mathrm{PHE} \mathrm{(dissolved} \mathrm{in} \mathrm{acetonitrile)} \mathrm{was} \mathrm{(Fig.} \mathrm{1a)}$ used for the qualitative analysis of PHE degradation. In this methods, mycelial disc (8.0 mm in diameter) of strain APC5 was transferred to BHA medium, then incubated at $27^{\circ} \mathrm{C}$ for 10 days. After the incubation, clearing zone formation was observed around the inoculated mycelia of $C$. byrsina strain APC5.

\subsection{Measurement of PHE degradation efficiency}

The PHE degradation experiment was performed in Erlenmeyer flasks $(250 \mathrm{~mL})$ containing $20 \mathrm{~mL}$ of previously prepared sterile MSB medium supplimented with PHE. Triplicate flasks were inoculated with culture mycelium of strain APC5 and incubated at $27^{\circ} \mathrm{C}$ under rotary shaker $(120 \mathrm{rpm})$ for 15 days. The sample were collected at regular 2 days of time interval during inubation period and residual PHE in the MSB medium and the ligninolytic enzyme production were investigated. At the same time, the control (without fungus culture) was incubated. The PHE degradation efficiency was measured as percent (\%) of degradation.

Degradation $(\%)=\left\{\left(C_{i}-C_{t}\right) / C_{i}\right\} \times 100$

Where $C_{i}$ - initial concentration of PHE (mg/L), $C_{t}$ - remaining concentration of PHE (mg/L) (Bishnoi et al., 2008). After the extraction, filtrate culture mycelium of strain APC5 were kept in a hot air oven at $50^{\circ} \mathrm{C}$, dried weight of mycelium (biomass) was observed.

\subsubsection{Extraction of PHE}

PHE and other existing organic compounds present in treated and untreated samples of PHE were extracted by liquidliquid extraction procedure with ethyl acetate as described previously by Agrawal and Shahi (2017). An equal volume of PHE degraded medium and ethyl acetate were taken for the extraction of metabolites. Obtained organic solvent phase of metabolites were dried under vaccum using rotary evaporator. Then obtained residues weredissolved in HPLC grade $2.0 \mathrm{~mL}$ acetonitrile and used for HPLC, FTIR, and GC-MS analysis.

\subsubsection{HPLC analysis}

The residual concentration of PHE was assessed with the help of HPLC chromatogram peak area. HPLC analysis was performed on UFLC model euquipped with a PDA detector system (Shimadzu prominence, Japan), $\mathrm{C}_{18}, 100 \mathrm{~A}^{\circ}$ column (Luna5u, $250 \times 4.6 \mathrm{~nm}$ ) and pump (LC - 20AT), detector (PDA) was used at $254 \mathrm{~nm}$ ). A gradient of solvent A and solvent $B$ acetonitrile and water (70:30) were applied at $1.0 \mathrm{~mL} / \mathrm{min}$ flow rate for $20 \mathrm{~min}$. The detection was 
observed at wavelength of $254 \mathrm{~nm}$ to measure the degradation of PHE. Remaining concentration of PHE was measured by the following formula;

Concentration of PHE in sample $(\mathrm{mg} / \mathrm{L})=\mathrm{A}_{\mathrm{SAM}} / \mathrm{A}_{\mathrm{STD}} \times \mathrm{C}_{\mathrm{STD}}$

Where $A_{S A M}$ - peak area of chromatogram of sample, $A_{S T D}$ - peak area of standard PHE compound, $\mathrm{C}_{S T D}$ concentration of standard PHE compound (mg/L)

\subsection{Identification of PHE degradation metabolies}

Extracted metabolites were analyzed by FTIR spectroscopy and GCMS.

\subsubsection{FTIR spectroscopy}

To access the bond modification of metabolies after degradation, FTIR spectroscopy analysis was performed in the range of $375-4000 / \mathrm{cm}$ using spectrophotometer (IR affinity-1, Shimadzu, Japan). The separated extract of metabolites were mixed with spectroscopic grade potassium bromide to prepare the pellet for FTIR analysis. At the same time IR spectra of PHE (control) was examined.

\subsubsection{GC-MS analysis}

The metabolites of degraded PHE were identified by GC-MS (Thermo Fisher Scientific, USA, GC model - Trace GC ultra, MS model - Polaris Q) with DB-5 MS capillary column (30 m length, $0.25 \mathrm{~mm}$ internal diameter and $0.25 \mu \mathrm{m}$ film thickness). The injection volume of sample was $1 \mathrm{~mL}$. The ion source of GC-MS was kept at $230^{\circ} \mathrm{C}$ and transfer line temperature along with inlet temperature was maintained at $280^{\circ} \mathrm{C}$. The temperature program kept for 2 min hold at $70^{\circ} \mathrm{C}$, an increase to $200^{\circ} \mathrm{C}$ at $10^{\circ} \mathrm{C}$ per min, kept for $1 \mathrm{~min}$ in $200^{\circ} \mathrm{C}$, then again increase temperature to $325^{\circ} \mathrm{C}$ at $5^{\circ} \mathrm{C}$ per min and hold for $15 \mathrm{~min}$ at $325^{\circ} \mathrm{C}$. Helium gas ( $1 \mathrm{~mL}$ per $\mathrm{min}$ ) was used as the carrier gas. The mass spectrometer was operated in an electron ionization mode of $70 \mathrm{eV}$ energy lon trap detector. The detected metabolites were identified by compairing with the MS library NIST (National institute of standard technology, USA) attached with the GC-MS instrument (Ghosal et al., 2010).

\subsection{Ligninolytic enzyme activity}

To assess the ligninolytic enzyme activity during PHE degradation, the culture supernatant was taken as per the protocol describe earlier (Sect. 2.4). LAC enzyme assay of collected treated supernanat was performed according to method described by Sandhu and Arora (1985), take $3 \mathrm{~mL}$ of solution containing $1.5 \mathrm{~mL}$ sodium acetate buffer (10 $\mathrm{mM}, \mathrm{pH} 5.0), 0.5 \mathrm{~mL}$ of the enzyme extract, $1 \mathrm{~mL}$ guaiacol $\left(2 \mathrm{mM}, \nabla_{450}=12100 / \mathrm{M}^{\prime} \mathrm{cm}\right)$, then incubate for $2 \mathrm{~h}$ and absorbance read at $450 \mathrm{~nm}$ using double beam UV-Visible spectrophotometer (ELICO SL 218, Andhra Pradesh, India). For the LiP assay, total $3 \mathrm{~mL}$ of reaction mixture containing $1 \mathrm{~mL}$ of $125 \mathrm{mM}$ sodium tartrate buffer (pH 3.0), $1 \mathrm{~mL}$ of $0.16 \mathrm{mM}$ azure $B\left(\nabla_{651}=48800 / \mathrm{M} / \mathrm{cm}\right), 0.5 \mathrm{~mL}$ of the culture filtrate and then add $0.5 \mathrm{~mL}$ of $2 \mathrm{mM}$ hydrogen peroxide. Then absorbance was recored at $651 \mathrm{~nm}$ (Archibald, 1992). MnP activity was analyzed by the method reported by de Jong et al. (1992). Take $3 \mathrm{~mL}$ of reaction mixture containing $1 \mathrm{~mL}$ of sodium tartrate buffer (50 mM, $\mathrm{pH} 4.0), 0.5 \mathrm{~mL}$ culture filtrate and $1 \mathrm{~mL}$ of $2 \mathrm{mM} 2,6-\mathrm{DMP}\left(\nabla_{468}=49600 / \mathrm{M} / \mathrm{cm}\right)$. The reaction was started with the addition of $0.5 \mathrm{~mL}$ hydrogen peroxide $(0.4 \mathrm{mM})$ by the oxidation of 2,6-DMP. The enzyme activity was expressed in terms of international units per liter of enzyme extract $(U / L)$.

\subsection{Optimization of culture conditions for the ligninolytic enzyme production and PHE degradation}

\subsubsection{Effect of physical parameters}


Ligninolytic enzyme production and PHE degrdadtion by strain APC5 was optimized in different physical parameters conditions like $\mathrm{pH}$, temperature, and salinity. During optimization experiment, MSB $(20 \mathrm{~mL})$ supplemented with 20 $\mathrm{mg} / \mathrm{L}$ PHE was inoculated by $8 \mathrm{~mm}$ diameter mycelial disc of strain APC5. Afterwards, inoculated flasks were incubated at varying $\mathrm{pH}(3.0-8.0)$, temperature $\left(15-55^{\circ} \mathrm{C}\right)$ and salinity $(10$ and $32 \mathrm{~g} / \mathrm{L})$ in the rotary shaker incubator (120 rpm) for 10 days. The PHE degradation and ligninolytic enzyme activity were determined as described earlier and protein concentration was analyzed according to the standard protocol of Lowry et al. (1951).

\subsubsection{Efect of different concentration of PHE}

To evaluate the effect of different concentration of PHE on the degradation by strain APC5, Erlenmeyer flasks containing different concentrations of PHE (10-100 mg/L) in MSB were inoculated by mycelial disc (8 mm diameter) of strain APC5 and flasks were incubated at $27^{\circ} \mathrm{C}$ in shaking flask condition (120 rpm) for 10 days. After incubation, the degradation of PHE was evaluated by HPLC analysis.

\subsection{Degradation of PHE in soil}

PHE degradation by $C$. byrsina strain APC5 was also investigated in the soil (in-vivo condition). For experiment, the soil was collected from village sendri, Bilaspur (Chhattisgarh) as prescribed earlier in Agrawal and Shahi (2017). The soil type was classified as loam soil, with 0.225 carbon (5\%), 275 nitrogen (kg/ha), 11.25 sulphur (kg/ha), 168 potassium (kg/ha) and $5.8 \mathrm{pH}, 0.14$ electro conductivity analyzed by soil testing lab, Dept. of Agriculture Bilaspur, Chhattisgarh. Sterilized soil was treated with $50 \mathrm{mg} / \mathrm{kg}$ of PHE (dissolved in acetonitrile).

\subsubsection{Inoculum preparation in wheat bran and talc powder substrate}

Fungal inoculum was prepared in two types of substrates: wheat bran and talc powder. Wheat bran inoculum (100 g) was prepared in the sterilized spawn bags with $14000 \mathrm{CFU}$ (colony forming unit)/g. To prepare talc powder inoculum, homogenized culture broths $(100 \mathrm{~mL}, 13300 \mathrm{CFU} / \mathrm{mL})$ were transferred and mixed with sterilized talc powder $(1 \mathrm{~kg})$ containing carboxy methyl cellulose (20 g, as a binder) and then dried, after drying inoculum was ready for application.

\subsubsection{Treatment of PHE incorporated soil with the inoculum}

Wheat bran and talc powder inoculum were mixed in PHE incorporated soil separately. Wheat bran inoculum treated soil (100 g/kg) and control sets (soil containing PHE and without any fungal inoculum) were kept in sterilized polythene bags and incubated at $27^{\circ} \mathrm{C}$ for 30 days and talc powder inoculum treated soil and control sets (soil containing PHE and without any fungal inoculum) were transferred in nursery bags. Nursery bags were incubated for thirty days in the outer environmental condition.

\subsubsection{PHE degradation analysis by HPLC}

PHE degraded metabolites were extracted from soil according to the method described by Zebulum et al. (2011). Briefly, control as well as treated soil samples were taken separately in Erlenmeyer flasks and mixed with $20 \mathrm{~mL}$ of acetonitrile and shake for $10 \mathrm{~min}$. To extract large number of metabolites from treated sample, the extraction procedure was repeated three times. Obtained extract was concentrated by vacuum evaporator. Concentrated extract was investigated with the help of HPLC to calculate the PHE degradation percentage.

\subsection{Phytotoxicity assessment of PHE degradation metabolites}

The phytotoxicity assessment control (untreated) and bioremediated soil were studied in the plant of Vigna radiata and Cicer arietinum. V. radiata (seed variety: LeelA seeds, Ahamdabad) and C. arietinum (seed variety: Research Bengal Gram Daftari 21) seeds were collected from Krishi Raksha Kendra, Bilaspur, Chhattisgarh. Prior to performing the experiment, the seeds surface were sterilized with $70 \%(\mathrm{v} / \mathrm{v})$ ethanol and $2 \%(\mathrm{v} / \mathrm{v})$ solution of sodium 
hypochlorite. Furthermore, repeated washing of seeds were performed with distilled water to remove the remaining sodium hypochlorite. Sterilized seeds of $V$. radiata and $C$. arietinum were sowed in control and treatment sets (In control sets, $50 \mathrm{mg} / \mathrm{L}$ of PHE was incorporated in $1 \mathrm{~kg}$ soil. In treatment sets, $50 \mathrm{mg} / \mathrm{L}$ of PHE incorporated in $1 \mathrm{~kg}$ soil was treated by fungal inoculum and after 30 days of incubation, bioremediated soil was used as treatment sets.). $V$. radiata seeds were sowed in wheat bran inoculated soil and $C$. arietinum seeds were sowed in talc powder inoculated soil. The control and treatment sets were kept in outer environmental condition for 30 days. After that plants were harvested from the soil. The length and weight (both dry and fresh) of the root and shoot, percentage of seed germination, root elongation and germination index (GI) were examined with the help of formulae as described earlier by Agrawal and Shahi (2017).

\subsection{Statistical analysis}

To avoid any type of experimental errors, each test of experiment was conducted in triplicate. The standard deviation was investigated with the help of Microsoft Excel (ver. 2019, Microsoft, United Kingdom) and results of experiments were presented in mean \pm SD value. The mean value of various test of control and experiment samples was investigated by one way ANOVA (analysis of variance) test by applying Dunnett's multiple comparison through Graph Pad Prism 8.0, (USA) statistical software.

\section{Results}

\subsection{Analysis of PHE degradation by plate assay}

C. byrsina culture was grown in BHA media (BHA media containing PHE used as control, (Fig. 1a), after incubation period, $7 \mathrm{~mm}$ clearing zone formation was observed around the mycelium because of the degradation of PHE (Fig. 1b).

\subsection{Measurement of PHE degradation efficiency}

PHE degradation by $C$. byrsina strain APC5 was examined after 2 days of regular time intervals by HPLC chromatogram. The HPLC chromatogram of control sample showed (Fig. 1C) a single major peak of PHE, while in fungi treated sample chromatogram (Fig. 1d) showed small peak of PHE and many extra peaks of other newly formed metabolites which clearly indicated the PHE degradation efficiency of strain APC5 by their ligninolytic enzyme activity. It was observed that as the incubation period increased, PHE degradation and biomass (Fig. 1e) of $C$. byrsina also increased, after 8 th day $83.40 \% \mathrm{PHE}(20 \mathrm{mg} / \mathrm{L})$ degradation was examined at $\mathrm{pH} 6.0$ and $27^{\circ} \mathrm{C}$ temperature while at 14th day of incubation 99.90\% PHE degradation was observed (Fig. 1e).

\subsection{Identification of PHE degradation metabolites}

FTIR analysis of $C$. byrsina treated PHE sample supported the degradation of PHE as compared with control because of the change in the functional groups of compounds (Fig. 2). The vibrational band frequesnices of PHE was found in FTIR spectroscopy between 2800 and $3200 \mathrm{~cm}^{-1}\left(3057 \mathrm{~cm}^{-1}\right)$ (Wu et al. 2010) (Fig. 2a, b). IR spectra (Fig. 2a, b) of compounds demonstrated different skeleton, stretching vibration of functional groups. A peak at $1716-1740 \mathrm{~cm}^{-1}$ was observed because of the existence of stretching vibration of $\mathrm{CO}$ bond in carboxyl, carboxylic acids and ketones. The absorption band at $1450-1625 \mathrm{~cm}^{-1}$ might appear as a result of skeleton vibration of benzene ring. At 1463

$\mathrm{cm}^{-1}, 610-700 \mathrm{~cm}^{-1}$, skeleton vibration of aromatic ring, $-\mathrm{C} \equiv \mathrm{C}-\mathrm{H}$ : $\mathrm{C}-\mathrm{H}$ bend in alkynes were investigated, because of ring cleavage reaction.

In this experiment, the GC-MS analysis of ethyl extracted untreated PHE (control), the peak of PHE was detected at the retention time (RT) $13.28 \mathrm{~min}$ (m/z 178) (Fig. 3a). However, after the 4th day treated sample, at the RT value 17.58 
min (m/z 210) 9, 10-DihydroxyPHE was investigated, (Fig. 3b). At RT value $16.23 \mathrm{~min}$ (m/z 166) phthalic acid was identified, after 8th day of incubation, (Fig. 4a). Acetic acid anhydride (RT $4.05 \mathrm{~min}, \mathrm{~m} / \mathrm{z}$ 102), Benzene octyl (RT $11.03 \mathrm{~min}, \mathrm{~m} / \mathrm{z}$ 190), 4-heptyloxy phenol (RT $15.73 \mathrm{~min}, \mathrm{~m} / \mathrm{z} 208$ ), 2, 2-Diphenic acid (RT $18.36 \mathrm{~min}, \mathrm{~m} / \mathrm{z}$ 242), 9, 10Dihydroxyphenanthrene (RT $21.10 \mathrm{~min}, \mathrm{~m} / \mathrm{z}$ 210) were observed (Fig. 4b) after 12th day of incubation. These metabolites were degraded products of PHE after fungi treatment.

On the basis of above identified metabolites, the PHE degradation pathway was postulated as shown in Fig. 5. PHE was first oxidized in K-region and transformed into 9, 10-dihydroxyphenanthrene by the action of LAC, LiP and MnP enzyme. Further 2, 2-diphenic acid and phthalic acid were produed due to the oxidation and ortho-ring cleavage reaction occurred by LAC, LiP and MnP enzyme. Due to side group removal phthalic acid converted into 4-heptyloxy phenol, benzene octyl, then ring cleavage reaction occurred by the ligninolytic enzyme, finally the conversion of acetic acid anhydride was observed after degradation.

\subsection{Ligninolytic enzyme activity}

To observe the ligninolytic activity during the PHE degradation, LAC, LiP and MnP activity of C. byrsina was investigated at regular 2 days time intervals. MnP activity was found maxium at the initial stage of PHE degradation whereas LAC activity was noted maximum $2629.00 \mathrm{U} / \mathrm{L}$ after 8th day incubated sample. LiP and MnP activity was found to be noted maximum 1727.00 U/L, $20147.00 \mathrm{U} / \mathrm{L}$ after 6 and 8 days of incubation respectively (Table 2). During the experiment it was observed that the degradation of PHE was significantly increased in the 6th day treated sample. 
Table 2

Ligninolytic enzyme production by C. byrsina in PHE containing MSB.

\begin{tabular}{|c|c|c|c|c|c|c|}
\hline Incubation & LAC activity (U/L) & & LiP activity (U/L) & & MnP activity (U/L) & \\
\hline & $\begin{array}{l}\text { Without PHE } \\
\text { (Agrawal and } \\
\text { Shahi, 2017) }\end{array}$ & With PHE & $\begin{array}{l}\text { Without PHE } \\
\text { (Agrawal and } \\
\text { Shahi, 2017) }\end{array}$ & $\begin{array}{l}\text { With } \\
\text { PHE }\end{array}$ & $\begin{array}{l}\text { Without PHE } \\
\text { (Agrawal and } \\
\text { Shahi, 2017) }\end{array}$ & With PHE \\
\hline 2 & $95.60 \pm 8.62$ & $\begin{array}{l}250.50 \pm \\
35.88^{\star \star \star}\end{array}$ & $272.30 \pm 35.61$ & $\begin{array}{l}646.40 \\
\pm \\
84.17^{\star \star \star}\end{array}$ & $367.00 \pm 47.75$ & $\begin{array}{l}882.30 \pm \\
31.89^{\star \star \star \star}\end{array}$ \\
\hline 4 & $368.10 \pm 15.12$ & $\begin{array}{l}460.40 \pm \\
65.46^{\text {ns }}\end{array}$ & $553.60 \pm 85.74$ & $\begin{array}{l}911.10 \\
\pm \\
47.24^{\star \star \star}\end{array}$ & $2183.00 \pm 40.86$ & $\begin{array}{l}5490.00 \\
\pm \\
17.74^{\star \star \star \star}\end{array}$ \\
\hline 6 & $729.50 \pm 21.73$ & $\begin{array}{l}814.70 \pm \\
83.26^{\text {ns }}\end{array}$ & $1170.00 \pm 306.80$ & $\begin{array}{l}1727.00 \\
\pm \\
210.60^{\star}\end{array}$ & $2932.00 \pm 234.60$ & $\begin{array}{l}6586.00 \\
\pm \\
415.30^{\star \star \star}\end{array}$ \\
\hline 8 & $1523.00 \pm 54.46$ & $\begin{array}{l}2629.00 \\
\pm \\
124.30^{\star \star \star \star}\end{array}$ & $938.80 \pm 135.20$ & $\begin{array}{l}1266.00 \\
\pm \\
58.10^{n s}\end{array}$ & $11020.00 \pm 31.34$ & $\begin{array}{l}20147.00 \\
\pm \\
669.40^{\star \star \star \star}\end{array}$ \\
\hline 10 & $893.70 \pm 67.88$ & $\begin{array}{l}1434.00 \\
\pm \\
106.80^{\star \star \star}\end{array}$ & $305.30 \pm 20.96$ & $\begin{array}{l}541.00 \\
\pm \\
111.60^{\mathrm{ns}}\end{array}$ & $\begin{array}{l}15987.00 \pm \\
130.60\end{array}$ & $\begin{array}{l}18969.00 \\
\pm \\
469.60^{\star \star \star}\end{array}$ \\
\hline 12 & $935.20 \pm 64.11$ & $\begin{array}{l}128.30 \pm \\
17.90^{\star \star \star \star}\end{array}$ & $318.20 \pm 22.22$ & $\begin{array}{l}687 . .20 \\
\pm 66.72^{*}\end{array}$ & $1847.00 \pm 259.20$ & $\begin{array}{l}4301.00 \\
\pm \\
458.60^{\star \star \star}\end{array}$ \\
\hline 14 & $307.00 \pm 21.78$ & $\begin{array}{l}381.50 \pm \\
8.66^{\text {ns }}\end{array}$ & $480.00 \pm 78.11$ & $\begin{array}{l}768.20 \\
\pm \\
97.06^{\mathrm{ns}}\end{array}$ & $2110.00 \pm 22.03$ & $\begin{array}{l}3391.00 \\
\pm \\
196.70^{\star \star}\end{array}$ \\
\hline
\end{tabular}

\subsection{Optimization of culture conditions for the ligninolytic enzyme production and degradation}

\subsubsection{Effect of physical parameters}

The effect of abiotic environmental parameters like $\mathrm{pH}$, temperature, and saline condition on the degrdadation of $\mathrm{PHE}$ showed that at pH 6.0 the maximum ligninolytic activity (1213.00 U/L LAC, 1028.00 U/L LiP, 7300.00 U/L MnP) and PHE degradation (85.60\%) was observed (Fig. 6 (a)). It showed that when the production of enzyme increased, the degradation of PHE was simultaneously increased. The highest biomass $(25.00 \mathrm{mg})$ and protein concentration $(261.50 \mathrm{mg} / \mathrm{L})$ were observed at $\mathrm{pH} 7.0$ and 8.0 respectively. Further more increase in $\mathrm{pH}$, inhibited the enzyme production, degradation and growth of fungi. Increase the incubation temperature upto $15-35^{\circ} \mathrm{C}$ enhanced the degradation and enzyme activity. The maximum activity of ligninolytic enzymes (LAC 1640.00 U/L, LiP 957.00 U/L, $\mathrm{MnP} 20800.00 \mathrm{U} / \mathrm{L}$, and degradation of PHE (87.50\%) and growth (248.50 mg biomass, $110.50 \mathrm{mg} / \mathrm{L} \mathrm{protein)} \mathrm{was}$ observed at optimum temperature of $25^{\circ} \mathrm{C}$ (Fig. 6b). Further increase in the temperature up $55^{\circ} \mathrm{C}$ adversely affected 
the degradation efficiency, enzyme activity, and growth of fungi. Similarly, at low salt concentration of $10 \mathrm{~g} / \mathrm{L}$, more enzyme activity (290.90 U/L LAC, $6799.00 \mathrm{U} / \mathrm{L}$ LiP, $2113.00 \mathrm{U} / \mathrm{L} \mathrm{MnP})$, degradation of PHE (34.50\%) and growth (150.00 mg biomass, $85.30 \mathrm{mg} / \mathrm{L}$ protein) of fungi was observed as compared to high salt concentration (32 $\mathrm{g} / \mathrm{L}$ : 10.30 U/L LAC, 2193.90 U/L LiP, 604.80 U/L MnP, 20.50\% PHE degradation, 100 mg biomass, $15.70 \mathrm{mg} / \mathrm{L}$ protein) (Fig. 6 (c)).

\subsubsection{Efect of different concentration of PHE}

When the concentration of PHE increased in the medium, it was observed that after 10 days of incubation the ligninolytic enzyme activity of organisms significantly increased $(p<0.0001)$ (Table 3 ) and the degradation \% of PHE decreased (Fig. 1f). At the 10 and 20 mg/L concentration of PHE maximum degradation up to $90.50 \%$ and $85.60 \%$ was observed. At 100 mg/L concentration of PHE, maximum Lac (3729.00 U/L), LiP (12911.00 U/L) and MnP (30247.00 U/L) activity was reported.

Table 3

Ligninolytic enzyme production by strain APC5 at different concentration of PHE.

\begin{tabular}{|llll|}
\hline Concentration of PHE $(\mathrm{mg} / \mathrm{L})$ & LAC activity $(\mathrm{U} / \mathrm{L})$ & LiP activity $(\mathrm{U} / \mathrm{L})$ & MnP activity $(\mathrm{U} / \mathrm{L})$ \\
\hline 0 & $1787.00 \pm 479.80$ & $1009.00 \pm 28.90$ & $11061.00 \pm 182.20$ \\
\hline 10 & $2556.00 \pm 347.50^{\star}$ & $1077.00 \pm 242.70 \mathrm{~ns}$ & $19887.00 \pm 287.30^{\star \star \star \star}$ \\
\hline 20 & $2629.00 \pm 124.30^{\star}$ & $1266.00 \pm 58.10 \mathrm{~ns}$ & $20147.00 \pm 669.40^{\star \star \star \star}$ \\
\hline 50 & $2622.00 \pm 206.90^{\star}$ & $8128.00 \pm 152.70^{\star \star \star \star}$ & $21588.00 \pm 545.60^{\star \star \star \star}$ \\
\hline 100 & $3729.00 \pm 196.70^{\star \star \star \star}$ & $12911.00 \pm 275.30^{\star \star \star \star}$ & $30247.00 \pm 446.60^{\star \star \star \star}$ \\
\hline
\end{tabular}

\subsection{Degradation of PHE in soil}

Degradation of PHE was investigated in soil through the analysis of HPLC chromatogram peak area. When wheat bran inoculum was applied $77.48 \%$ of PHE degradation was investigated, whereas $68.74 \%$ of PHE degradation was observed with the talc powder inoculum.

\subsection{Phytotoxicity assessment of PHE degraded metabolites}

The phytotoxicity of control (PHE contaminated) and treated soil (bioremediated soil) sample was investigated by observing GI index, germination \%, measuring the length and weight of root and shoot of the both $\mathrm{V}$. radiata and $C$. arietinum plant shown in Fig. 7, and Table 4. In present study, the $100 \%$ seed germination was observed in control and treated soil sample plants of $V$. radiata and $C$. arietinum. It was observed that control sample was highly toxic, only $51.89 \%$ and $38.89 \%$ GI was found in the control plants of $V$. radiata and C. arietinum respectively, however $218.56 \%$ and $101.83 \% \mathrm{GI}$ were found in the treated sample plants of $V$. radiata and $C$. arietinum respectively, which defines no toxicity of PHE degradation metabolites towards the plant. 
Table 4

Phytotoxicity effect of PHEdegtaded metaboliteson Vigna radiata and Cicer arietinum.

\begin{tabular}{|c|c|c|c|c|c|c|}
\hline \multirow[b]{2}{*}{ Parameter } & \multicolumn{3}{|c|}{ Vigna radiata } & \multicolumn{3}{|l|}{ Cicer arietinum } \\
\hline & $\begin{array}{l}\text { Native } \\
\text { soil }\end{array}$ & $\begin{array}{l}\text { PHE } \\
\text { contaminated } \\
\text { soil }\end{array}$ & $\begin{array}{l}\text { Bioremediated } \\
\text { soil }\end{array}$ & $\begin{array}{l}\text { Native soil } \\
\text { (Agrawal and } \\
\text { Shahi,2017) }\end{array}$ & $\begin{array}{l}\text { PHE } \\
\text { contaminated } \\
\text { soil }\end{array}$ & $\begin{array}{l}\text { Bioremediated } \\
\text { soil }\end{array}$ \\
\hline $\begin{array}{l}\text { Root Length } \\
(\mathrm{cm})\end{array}$ & $\begin{array}{l}9.00 \pm \\
1.4\end{array}$ & $4.67 \pm 0.58$ & $19.67 \pm 4.5^{\star}$ & $18.00 \pm 3.00$ & $7.00 \pm 2.5$ & $18.33 \pm 0.58$ ** \\
\hline $\begin{array}{l}\text { Shoot } \\
\text { Length (cm) }\end{array}$ & $\begin{array}{l}39.80 \\
\pm 0.24\end{array}$ & $9.33 \pm 1.16$ & $23.00 \pm 2.6^{\star \star \star}$ & $37.33 \pm 0.58$ & $15.33 \pm 5.7$ & $35.67 \pm 5.5^{\star \star \star}$ \\
\hline $\begin{array}{l}\text { Fresh Root } \\
\text { Weight (gm) }\end{array}$ & $\begin{array}{l}0.045 \\
\pm \\
0.002\end{array}$ & $0.03 \pm 0.016$ & $0.07 \pm 0.03^{\mathrm{ns}}$ & $0.63 \pm 0.15$ & $0.09 \pm 0.01$ & $0.58 \pm 0.13^{\star \star}$ \\
\hline $\begin{array}{l}\text { Fresh Shoot } \\
\text { Weight (gm) }\end{array}$ & $\begin{array}{l}4.43 \pm \\
0.33\end{array}$ & $0.18 \pm 0.06$ & $1.50 \pm 0.13^{\mathrm{ns}}$ & $1.22 \pm 0.16$ & $0.23 \pm 0.03$ & $1.25 \pm 0.25^{\star \star}$ \\
\hline $\begin{array}{l}\text { Dry Root } \\
\text { Weight (gm) }\end{array}$ & $\begin{array}{l}0.028 \\
\pm \\
0.002\end{array}$ & $0.017 \pm 0.008$ & $0.03 \pm 0.01^{\mathrm{ns}}$ & $0.08 \pm 0.01$ & $0.02 \pm 0.003$ & $0.06 \pm 0.02 *$ \\
\hline $\begin{array}{l}\text { Dry Shoot } \\
\text { Weight (gm) }\end{array}$ & $\begin{array}{l}0.93 \pm \\
0.007\end{array}$ & $0.052 \pm 0.007$ & $0.46 \pm 0.05^{\star \star \star}$ & $0.54 \pm 0.37$ & $0.04 \pm 0.006$ & $0.14 \pm 0.04^{\star \star}$ \\
\hline $\begin{array}{l}\text { Germination } \\
\%\end{array}$ & 100 & 100 & 100 & 100 & 100 & 100 \\
\hline $\begin{array}{l}\text { Root } \\
\text { elongation \% }\end{array}$ & - & 51.89 & 218.56 & -- & 38.89 & 101.83 \\
\hline $\begin{array}{l}\text { Germination } \\
\text { Index (GI) }\end{array}$ & - & 51.89 & 218.56 & -- & 38.89 & 101.83 \\
\hline $\begin{array}{l}\text { Values repres } \\
\text { ANOVA analy } \\
0.0001,{ }^{* *} p<\end{array}$ & $\begin{array}{l}\text { of thre } \\
\text { the val } \\
01, * \star\end{array}$ & $\begin{array}{l}\text { dependent repl } \\
\text { represent in } c c \\
.01 \text { and } * p<0 \text {. }\end{array}$ & $\begin{array}{l}\text { ate }(n=3) \text { with } \\
\text { mn are signific } \\
\text {. }\end{array}$ & $\begin{array}{l}\text { an } \pm \text { standard } \\
\text { t different, ns- }\end{array}$ & $\begin{array}{l}\text { tion. Accordin } \\
\text { gnificant } p>0 \text {. }\end{array}$ & $\begin{array}{l}\text { o one way } \\
5, * \star \star * p<\end{array}$ \\
\hline
\end{tabular}

As compared to control the root, shoot length of treated $V$. radiata plants increased $p<0.05, p<0.001$ significantly. The root length of $V$. radiata plant was observed in bioremediated soil, 4.2 and 2.2 times longer than the seed showed in the soil of PHE contaminated and native soil respectively. In the case of shoot length of $V$. radiata 4.27 and 1.73 times reduction were found in PHE contaminated and bioremediated soil plant as compared to native plant. 51.89 germination index was found in the PHE contaminated soil, while 218.56 germination index was observed in the bioremediated soil which represents the non toxic condition of soil after the degradation of PHE by $C$. byrsina fungus.

In the case of $C$. arietinum plants, as compared to control the root, shoot length of bioremmediated soil plants was increased $p<0.01, p<0.001$ significantly. The root length of $C$. arietinum plant was observed in bioremediated soil, 2.62 times longer than the seed showed in the soil of PHE contaminated. The shoot length of $C$. arietinum 2.44 times reduction were found in PHE contaminated as compared to native plant. 38.89 germination index was found in the PHE contaminated soil, while 101.83 germination index was observed in the bioremediated soil which represents the non toxic condition of soil after the degradation of PHE by $C$. byrsina fungus. On the basis of above data, it was investigated that after the degradation of PHE from soil any types of toxic metabolites were not formed, GI index and the vegetative growth parameters of $V$. radiata and $C$. arietinum plants increased significantly. 


\section{Discussion}

PAHs transformation by wood decaying ligninolytic white rot fungi might be a universal phenomenon (Mao and Guan, 2016; Park et al., 2019). In this experiment, we demonstrated that white rot fungi $C$. byrsina strain APC5 have a high ability to degrade $99.90 \%$ of $20 \mathrm{mg} / \mathrm{L}$ PHE after 14 days of incubation in MSB. In the previous study. Hadibarata and Tachibana (2010) investigated that Polyporus sp. S133 degraded 92\% of $1 \mathrm{mmol} / \mathrm{L}$ PHE after 30 days of incubation with $120 \mathrm{rpm}$ agitation in MSB and 44\% degradation in non-agitated culture. Wu et al. (2016) reported that Pleurotus eryngii degraded $61.21 \%$ of 20 mg/L PHE after 15 days incubation in Potato dextrose liquid (PDL) medium while Pozdnyakova et al. (2018) investigated $P$. ostreatus D1 degraded $95.10 \pm 2 \%$ of 50 mg/L PHE in Kirk's medium after 21 days of incubation shown in Table 1. As we known, PHE is degraded by different white rot fungi like $P$. ostreatus, Ganoderma lucidum, Phanerochaete Chrysosporium, Trametes versicolor (Bumpus, 1989; Dhawale et al., 1992; Han et al., 2004; Sutherland et al., 1991; Ting et al., 2011), but in this study white rot fungus $C$. byrsina strain APC5 is first time reported for the degradation of PHE.

Table 1

Comparison of PHE degradation by Coriolopsisbyrsinastrain APC5 with some other reference fungi.

\begin{tabular}{|c|c|c|c|c|c|c|c|}
\hline $\begin{array}{l}\text { S. } \\
\text { No. }\end{array}$ & $\begin{array}{l}\text { White rot } \\
\text { fungi }\end{array}$ & $\begin{array}{l}\text { PHE } \\
\text { concentration }\end{array}$ & $\begin{array}{l}\text { Degradation } \\
(\%)\end{array}$ & Enzymes & $\begin{array}{l}\text { Incubation } \\
\text { medium }\end{array}$ & $\begin{array}{l}\text { Incubation } \\
\text { period } \\
\text { (days) }\end{array}$ & References \\
\hline 1. & $\begin{array}{l}\text { Coriolopsis } \\
\text { byrsina }\end{array}$ & $20 \mathrm{mg} / \mathrm{L}$ & 99.90 & Lac, LiP, MnP & $\begin{array}{l}\text { Mineral } \\
\text { salt broth }\end{array}$ & 14 & Present work \\
\hline 2. & $\begin{array}{l}\text { Pleurotus } \\
\text { ostreatus } \\
D 1\end{array}$ & $50 \mathrm{mg} / \mathrm{L}$ & $95.10 \pm 20$ & $\begin{array}{l}\text { Lac, MnP, } \\
\text { Versatile } \\
\text { peroxidase }\end{array}$ & $\begin{array}{l}\text { Kirk's } \\
\text { medium }\end{array}$ & 21 & $\begin{array}{l}\text { Pozdnyakova } \\
\text { et al. (2018) }\end{array}$ \\
\hline 3. & $\begin{array}{l}\text { Pleurotus } \\
\text { eryngii }\end{array}$ & $20 \mathrm{mg} / \mathrm{L}$ & 61.21 & $\begin{array}{l}\text { Lac, MnP, } \\
\text { Superoxide } \\
\text { dismutase }\end{array}$ & $\begin{array}{l}\text { Potato } \\
\text { dextrose } \\
\text { liquid } \\
\text { medium }\end{array}$ & 15 & $\begin{array}{l}\text { Wu et al. } \\
\text { (2016) }\end{array}$ \\
\hline 4. & $\begin{array}{l}\text { Ganoderma } \\
\text { lucidum } \\
\text { strain } \\
\text { BCRC36021 }\end{array}$ & $10 \mathrm{mg} / \mathrm{L}$ & 98.70 & Lac & $\begin{array}{l}\text { Basal } \\
\text { medium }\end{array}$ & 10 & $\begin{array}{l}\text { Ting et al. } \\
(2011)\end{array}$ \\
\hline 5. & $\begin{array}{l}\text { Polyporus } \\
\text { sp. S133 }\end{array}$ & $1 \mathrm{mmol} / \mathrm{L}$ & 92 & $\begin{array}{l}\text { Lac, LiP, MnP, } \\
\text { 1,2- } \\
\text { Dioxygenase, } \\
2,3- \\
\text { Dioxygenase }\end{array}$ & $\begin{array}{l}\text { Mineral } \\
\text { salt broth }\end{array}$ & 30 & $\begin{array}{l}\text { Hadibarata } \\
\text { and } \\
\text { Tachibana } \\
(2010)\end{array}$ \\
\hline
\end{tabular}

Ligninolytic enzyme of white rot fungi was described as the key for degradation of PAHs (Ghosal et al., 2016; Kunjadia et al., 2016; Qian and Chen, 2012). Our data represented that $C$. byrsina fungi produced significant amount $(p<0.0001)$ of ligninolytic enzyme therefore degrade PHE more efficiently. $C$. byrsina strain APC5 produced $2629 \mathrm{U} / \mathrm{L}$ LAC, 1727 U/L LiP, 20147 U/L MnP enzyme in the PHE containing media, while previously maximum 2000 U/L LAC activity was observed in C. byrsina SXS16 in the wheat bran substrate, but the activity of LiP and MnP was very low as compared to LAC reported by Gomes et al. (2009), although in the presence of PHE in MSB C. byrsina produced much higher amount of these three types of enzymes. While other PHE degrading fungi $P$. eryngii showed (996.25 U/L) LAC activity (Wu et al., 2016) and Polyporus sp. S133 showed 77.60 U/L LAC activity, 54.30 U/L LiP activity and 69.70 U/L MnP activity in MSB (with PHE) after 15 days of incubation (Hadibarata and Tachibana, 2010). 
The metabolites of PHE degradation identified by GC-MS were 1, 2 dihydroxy phenanthrene, 4-heptyloxy phenol, benzene octyl and acetic acid anhydride. During degradation, toxic metabolites like quinones, which is formed after the degradation of PAHs by many other fungi (Singh, 2006) were not detected in GC-MS analysis. PHE was oxidized at K-region by the ligninolytic enzyme and formed 1, 2 dihydroxy PHE. Kadri et al. (2017) and Pozdnyakova et al. (2018) also supported that ligninolytic enzymes are responsible for the initial oxidation of PAHs. After that the formation of 2, 2-Diphenic acid was investigated by the oxidation and ring cleavage reaction occurred by enzymes. 2, 2-Diphenic acid produced in P. chrysosporium by the action of MnP and LiP enzyme investigated by Hammel et al. (1992), Hammel, (1995). Further produced phthalic acid entered into basal metabolism (also suggested by Pozdnyakova et al. $(2010,2018)$ ). Our data support the degradation pathway described by Bezalel et al. (1997); Hadibarata and Tachibana, (2010). On the basis of above results, the detected metabolites of PHE was transformed and mineralized by $C$. byrsina strain APC5 through their enzyme activity.

PHE is considered as an indicator or model compound for the PAHs degradation study, because their presence in high concentration in the PAHs polluted sites and contain K-region and bay-region which are present in the structure of higher molecular weight PAHs (Bezalel et al., 1996; Sack et al., 1997). The efficiency of PAHs degradation depends on the production of ligninolytic enzyme (Kim et al., 1998; Field et al., 1992). Therefore to check the PAHs removal efficiency by strain APC5 in the contaminated area, different physical parameters and the concentration of PHE were optimized for the production of ligninolytic enzyme and PHE degradation. In this study Coriolopsis fungi showed ligninolytic enzyme activity in the temperature range $15-55^{\circ} \mathrm{C}$ at 3 to $8 \mathrm{pH}$, therefore able to degrade $\mathrm{PHE}$ in $\mathrm{pH}$ and temperature stress condition, while most fungi have shown maximum growth and ligninolytic activity at $\mathrm{pH} 3$ to 6 (Yamanaka et al., 2008). Tekere et al. (2001) investigated that the optimum temperature for the growth of T. versicolor is $30^{\circ} \mathrm{C}$. Han et al. (2004) investigated that PHE degradation by $T$. versicolor was maximum at pH 6.0 and $30^{\circ} \mathrm{C}$ temperature. In the present investigation the best temperature for the ligninolytic enzyme production, $\mathrm{PHE}$ degradation and growth of $\mathrm{C}$. byrsina is $25^{\circ} \mathrm{C}$ at $\mathrm{pH} 6.0$.

Salinity stress also affects the PHE degradation, fungal growth and enzyme production. Dixon et al. (1993) reported that every single fungus has revealed their different salt tolerance capacity due to their changed cell characteristics. In the presence of $10 \mathrm{~g} / \mathrm{L}$ of salt Coriolopsis fungi showed high growth, PHE degradation and enzymatic activity. As the salt concentration increased fungal growth, PHE degradation and enzyme production decreased. Kamei et al. (2008) also reported that the growth of $P$. chrysosporium and $T$. versicolor was supressed in $32 \mathrm{~g} / \mathrm{L}$ sea salt concentration. But at the salt concentration of $32 \mathrm{~g} / \mathrm{L}$ Coriolopsis fungi showed their growth, enzyme production and degradation.

The production of ligninolytic enzyme by fungi dependent on the concentration of carbon and nitrogen in the medium (D’Souza et al., 1999). It was investigated that as the concentration of PHE increased in the medium, the production of ligninolytic enzyme was increased significantly $(p<0.0001)$, which assist in the degradation of higher concentration of PHE by Coriolopsis fungi.

Formulation of $C$. byrsina effectively degraded PHE from soil. Degradation of PAHs in soil cannot be considered complete bioremediation of soil due to the formation of toxic metabolites after degradation or incomplete degradation of PAHs enhanced the, soil toxicity (Singh, 2006). Therefore phytotoxicity of PHE and their degraded metabolites were determined in the present study. After that we can say that $C$. byrsina strain APC5 is a potent PHE degrader from the environment and also promote the growth of plants.

\section{Conclusions}


This study shows that $C$. byrsina strain APC5 capable of degrading recalcitrant compound, PHE (PAHs) in in-vitro and in-vivo conditions. $C$. byrsina produced significant amounts $(\mathrm{p}<0.0001)$ of ligninolytic enzyme at different concentrations of PHE. C. byrsina also degrade PHE and produced ligninolytic enzyme in worst environmental condition like $\mathrm{pH}(3.0$ to 8.0$)$, temperature $\left(15\right.$ to $\left.55^{\circ} \mathrm{C}\right)$ and salinity $(10$ and $32 \mathrm{~g} / \mathrm{L})$. After the degradation of PHE by C. byrsina any types of toxic metabolites like quinone was not formed and toxicity of soil reduces therefore germination index and plant growth increases. $C$. byrsina can be used further in the process of phytoremediation as well as plant growth improvement. Furthermore, genetic engineering play a significant role in the enhancement of phytoremediation, to combine the knowledge of system biology with gene editing and gene manipulation technique efficiency of phytoremediation can be increased.

\section{Declarations}

\section{Acknowledgements}

The authors are thankful to Anand Barapatre, Senior Technical Assistant at Department of Pharmacy, Indira Gandhi National Tribal University, Amarkantak, Madhya Pradesh, India, for their support in the statistical analysis of generated data. The authors are also greatful to Swaroop Biswas, Junior Lab Assiatant, Smriti Ranjan Maji, Technical Officer at CIF-PD Lab Bose Institute, Kolkata for HPLC and GC-MS analysis. The authors are thankful to Head, Department of Botany, Guru Ghasidas Vishwavidyalaya, providing infrastructural facilities. Also, thank to Guru Ghasidas Vishwavidyalaya, Bilaspur (C.G.) for their financial assistance.

\section{Funding}

Not applicable

\section{Authors' contributions}

Nikki Agrawal: performed the experiments and completed the manuscript writing. Vineet Kumar: Manuscript writing and editing. Sushil Kumar Shahi: guided during research experiments and manuscript writing, reviewing and editing. All the authors approved the final manuscript.

\section{Ethical approval}

All the authors have read and agreed to the ethics of publishing the manuscript.

\section{Consent for publication}

Not applicable

\section{Consent to participate}

Not applicable.

\section{Declaration of interest}

The authors declare that they have no known competing interests that could have appeared to influence the reseach work described in this paper.

\section{Availability of data and material}


The gene sequence data of Coriolopsis byrsina strain APC5 were deposited in NCBI GenBank database and assigned the accession number KY418163.1, https://www.ncbi.nIm.nih.gov/nuccore/KY418163

\section{References}

Abdel-Shafy, H. I., \& Mansour, M. S. M. (2015). A review on polycyclic aromatic hydrocarbons: source, environmental impact, effect on human health and remediation. Egypt J. Pet. 25, 107-123.

Agrawal, N., Shahi, S. K. (2017). Degradation of polycyclic aromatic hydrocarbon (pyrene) using novel fungal strain Coriolopsis byrsina strain APC5. International Biodeterioration and Biodegradation, 122, 69-81.

Agrawal, N., Verma, P., Shahi, S. K. (2018). Degradation of polycyclic aromatic hydrocarbons (phenanthrene and pyrene) by the ligninolytic fungi Ganoderma lucidum isolated from the hardwood stump. Bioresources and Bioprocessing, 5(1), 11.

Ainerua, M. O., Tinwell, J., Murphy, R., Galli, G. L., van Dongen, B. E., White, K. N., \& Shiels, H. A. (2021). Prolonged phenanthrene exposure reduces cardiac function but fails to mount a significant oxidative stress response in the signal crayfish (Pacifastacus leniusculus). Chemosphere, 268, 129297.

Antosova, B.; Hrabak, P.; Antos, V.; Waclawek, S. 2020. Chemical oxidation of polycyclic aromatic hydrocarbins in water by ferrates (VI). Ecol. Chem. Eng. S. Inz. Ekol. S, 27, 529-542.

Archibald, F. S. (1992). A new assay for lignin type peroxidase employing the dye Azure B. Applied and Environment Microbiology, 58, 3110-3116.

Arora, D. S., Gill, P. K. (2001). Comparison of two assay procedures for lignin peroxidase. Enzyme and Microbial Technology, 28, 602-605.

Asgher, M., Bhatti, H. N., Ashraf, M., Legge, R. L. (2008). Recent developments in biodegradation of industrial pollutants by white rot fungi and their enzyme system. Biodegradation, 19, 771-783.

Balaji, V., Ebenezer, P., 2008. Optimization of extracellular lipase production in Colletotrichum gloeosporioides by solid state fermentation. Indian J. Sci. Technol. 1, 1-8.

Bandowe, B. A. M., Leimer, S., Meusel, H., Velescu, A., Dassen, S., Eisenhauer, N, Hoffmann T., Oelmann Y \& Wilcke, W. (2019). Plant diversity enhances the natural attenuation of polycyclic aromatic compounds (PAHs and oxygenated PAHs) in grass land soils. Soil Biology and Biochemistry, 129, 60-70.

Bankole, P. O., Semple, K. T., Jeon, B. H., \& Govindwar, S. P. (2021). Biodegradation of fluorene by the newly isolated marine-derived fungus, Mucor irregularis strain bpo1 using response surface methodology. Ecotoxicology and Environmental Safety, 208, 111619.

Bezalel, L., Hadar, Y., Cerniglia, C. E. (1997). Enzymatic mechanisms involved in phenanthrene degradation by the white rot fungus Pleurotus ostreatus. Applied and Environment Microbiology, 63(7), 2495-2501.

Bezalel, L., Hadar, Y., Fu, P. P., Freeman, J. P., Cerniglia, C. E. (1996). Metabolism of phenanthrene by the white rot fungus Pleurotus ostreatus. Applied and Environment Microbiology, 62(7), 2547-2553. 
Biko, O. D., Viljoen-Bloom, M., \& Van Zyl, W. H. (2020). Microbial lignin peroxidases: Applications, production challenges and future perspectives. Enzyme and Microbial Technology, 141:109669.

Bishnoi, K., Kumar, R., Bishnoi, N. R. (2008). Biodegradation of polycyclic aromatic hydrocarbons by white rot fungi Phanerochaete chrysosporium in sterile and unsterile soil. Journal of Scientific and Industrial Research, 67, 538-542.

Budavari, S., O'Neil, M. J., Smith, A. (1989). (Ed.) The Merck Index, Merck \& Co., Inc. Rahway, NJ, 143-1144.

Bumpus JA (1989) Biodegradation of polycyclic aromatic hydrocarbons by Phanerochaete chrysosporium. Appl Environ Microbiol 55:154-158.

Chen, K., Zhu, Q., Qian, Y., Song, Y., Yao, J., \& Choi, M. M. (2013). Microcalorimetric investigation of the effect of nonionic surfactant on biodegradation of pyrene by PAH-degrading bacteria Burkholderia cepacia. Ecotoxicology and environmental safety, 98, 361-367.

Czaplicki, L. M., Dharia, M., Cooper, E. M., Ferguson, P. L., \& Gunsch, C. K. (2018). Evaluating the mycostimulation potential of select carbon amendments for the degradation of a model PAH by an ascomycete strain enriched from a superfund site. Biodegradation, 29(5), 463-471.

de Jong, Ed., Field, J. A., de Bont, J. A. (1992). Evidence for a new extracellular peroxidase manganese inhibited peroxidase from the white rot fungus Bjerkandera sp. BOS 55. FEBS Letters. 299, 107-110.

Dhawale SW, Dhawale SS, Dean-Ross D (1992) Degradation of Phenanthrene by Phanerochaete Chrysosporium occurs under ligninolytic as well as non ligninolytic conditions. Appl Environ Microbiol 58:3000-3006.

Dixon RK, Rao MV, Garg VK (1993) Salt stress affects in vitro growth and in situ symbioses of ectomycorrhizal fungi. Mycorrhiza 3:63-68.

D'Souza, T. M., C. S. Merrit \& C. A. Reddy (1999) Lignin-modifying enzymes of the white rot basidiomycete Ganoderma lucidum. Applied and Environmental Microbiology, 65, 5307-5313.

Emami, E., Zolfaghari, P., Golizadeh, M., Karimi, A., Lau, A., Ghiasi, B., \& Ansari, Z. (2020). Effects of stabilizers on sustainability, activity and decolorization performance of Manganese Peroxidase enzyme produced by Phanerochaete chrysosporium. Journal of Environmental Chemical Engineering, 8(6), 104459.

Falciglia, P. P., Lumia, L., Giustra, M. G., Gagliano, E., Roccaro, P., Vagliasindi, F. G., \& Di Bella, G. (2020). Remediation of petrol hydrocarbon-contaminated marine sediments by thermal desorption. Chemosphere, 260, 127576.

Field, J. A., de Jong, E., Costa, G. F., de Bont, J. A. M. (1992). Biodegradation of polycyclic aromatic hydrocarbons by new isolates of white rot fungi. Applied and Environment Microbiology, 58, 2219-2226.

Garcia-Uitz, K., Moreno-Andrade, I., Hernandez-Nunez, E., Corona-Cruz, A., Giacoman-Vallejos, G., Ponce-Caballero, C. (2016). Degradation of phenanthrene by natural consortia in seawater. Romanian Biotechnological Letters 21, 1119511200.

Ghosal, D., Chakraborty, J., Khara, P., Dutta, T. K. (2010). Degradation of phenanthrene via meta-cleavage of 2-hydroxy1-naphthoic acid by Ochrobactrum sp. strain PWTJD. FEMS Microbiology Letters, 313, 103-110.

Ghosal, D., Ghosh, S., Dutta, T.K., Ahn, Y., 2016. Current state of knowledge in microbial degradation of polycyclic aromatic hydrocarbons (PAHs): a review. Front. Microbiol. 7, 1369. 
Gitipour, S., Sorial, G. A., Ghasemi, S., and Bazyari, M. (2018). Treatment technologies for PAH-contaminated sites: a critical review. Environ. Monit. Assess. 190, 1-17.

Gomes, E., Aguiar, A. P., Carvalho, C. C., Bonfa, M. R. B., Silva, R. D., Boscolo, M. (2009). Ligninases production by Basidiomycetes strains on lignocellulosic agricultural residues and their application in the decolorization of synthetic dyes. Brazilian Journal of Microbiology 40, 31-39.

Hadibarata, T., Kristanti, R. A. (2012). Fate and cometabolic degradation of benzo[a]pyrene by white rot fungus Armillaria sp. F022. Bioresource Technology, 107, 314-318.

Hadibarata, T., Tachibana, S. (2010). Characterization of phenanthrene degradation by strain Polyporus sp. S133. Journal of Environment Science, 22, 142-149.

Hammel, K. E. (1995). Mechanisms for polycyclic aromatic hydrocarbon degradation by ligninolytic fungi. Environmental Health Perspectives, 103(5), 41.

Hammel, K. E., Gai, W. Z., Green, B., Moen, M. A. (1992). Oxidative degradation of phenanthrene by the ligninolytic fungus Phanerochaete chrysosporium. Applied and Environment Microbiology, 58, 1832-1838.

Han MJ, Choi HT, Song HG (2004) Degradation of phenanthrene by Trametes versicolor and its laccase. J Microbiol 42:94-98.

Han, M. J., Choi, H. T., Song, H. G. (2004). Degradation of phenanthrene by Trametes versicolor and its laccase. Journal of Microbiology, 42, 94-98.

Haritash, A. K., Kaushik, C. P. (2009). Biodegradation aspects of polycyclic aromatic hydrocarbons (PAHs): a review. Journal of Hazardous materials, 169, 1-15.

Hidayat, A., \& Yanto, D. H. Y. (2018). Biodegradation and metabolic pathway of phenanthrene by a new tropical fungus, Trametes hirsuta D7. Journal of Environmental Chemical Engineering, 6(2), 2454-2460.

IARC (International Agency for Research on Cancer) (1983). IARC monographs on the evaluation of carcinogenic risks to humans, polynuclear aromatic compounds, part 1, Chemical, Environmental and Experimental Data, World Health Organization, Lyon, France, 32, 419-430.

Idowu, O., Semple, K. T., Ramadass, K., O'Connor, W., Hansbro, P., \& Thavamani, P. (2019). Beyond the obvious: Environmental health implications of polar polycyclic aromatic hydrocarbons. Environment international, 123, 543557.

Ike, P. T. L., Birolli, W. G., Dos Santos, D. M., Porto, A. L. M., \& Souza, D. H. F. (2019). Biodegradation of anthracene and different PAHs by a yellow laccase from Leucoagaricus gongylophorus. Environmental Science and Pollution Research, 26(9), 8675-8684.

Jia, Y., Chen, Y., Luo, J., \& Hu, Y. (2019). Immobilization of laccase onto meso-MIL-53 (Al) via physical adsorption for the catalytic conversion of triclosan. Ecotoxicology and environmental safety, 184, 109670.

Kadri, T., Rouissi, T., Brar, S. K., Cledon, M., Sarma, S., Verma, M. (2017). Biodegradation of polycyclic aromatic hydrocarbons (PAHs) by fungal enzymes: A review. Journal of Environment Science, 51, 52-74. 
Kalugina, O. V., Mikhailova, T. A., \& Shergina, O. V. (2018). Contamination of Scots pine forests with polycyclic aromatic hydrocarbons on the territory of industrial city of Siberia, Russia. Environmental Science and Pollution Research, 25(21), 21176-21184.

Kamei I, Daikoku C, Tsutsumi Y, Kondo R (2008) Saline-dependent regulation of manganese peroxidase genes in the hypersaline tolerant white rot fungus Phlebia sp. strain MG-60. Appl Environ Microbiol 74:2709-2716.

Kim, M. S., Huh, E. J., Kim, H. K., Moon, K. W. (1998). Degradation of polycyclic aromatic hydrocarbons by selected white-rot fungi and the influence of lignin peroxidase. Journal of Microbiology and Biotechnology, 8, 129-133.

Kunjadia PD, Sanghvi GV, Kunjadia AP, Mukhopadhyay PN, Dave GS (2016) Role of ligninolytic enzymes of white rot fungi (Pleurotus spp.) grown with azo dyes. SpringerPlus 5:1487.

Li, F., Zhang, Y., Wang, S., Li, G., Yue, X., Zhong, D., Chena C. \& Shen, K. (2020). Insight into ex-situ thermal desorption of soils contaminated with petroleum via carbon number-based fraction approach. Chemical Engineering Journal, 385, 123946.

Li, H.; Qu, R.; Li, C.; Guo, W.; Han, X.; He, F.; Ma, Y.; Xing, B. 2014. Selective removal of polycyclic aromatic hydrocarbons (PAHs) from soil washing effluents using biochars produced at different pyrolytic temperatures. Bioresour. Technol., 163, 193-198.

Li, S., Luo, J., Hang, X., Zhao, S., and Wan, Y. (2019). Removal of polycyclic aromatic hydrocarbons by nanofiltration membranes: rejection and fouling mechanisms. J. Membrane Sci. 582, 264-273.

Liu, S., Guo, C., Lin, W., Wu, F., Lu, G., Lu, J., \& Dang, Z. (2017). Comparative transcriptomic evidence for Tween80enhanced biodegradation of phenanthrene by Sphingomonas sp. GY2B. Science of the Total Environment, 609, 11611171.

Llorens-Blanch, G., Parlade, E., Martinez-Alonso, M., Gaju, N., Caminal, G., Blanquez, P. (2018). A comparison between biostimulation and bioaugmentation in a solid treatment of anaerobic sludge: Drug content and microbial evaluation. Waste Management, 72, 206-217.

Lowry, O. H., Rosebrough, N. J., Farr, A. L., Randall, R. J. (1951). Protein measurement with folin-phenol reagent. Journal of Biological Chemistry, 193, 265-275.

Luo, K., Carmella, S. G., Zhao, Y., Tang, M. K., \& Hecht, S. S. (2020). Identification and quantification of phenanthrene ortho-quinones in human urine and their association with lipid peroxidation. Environmental Pollution, 266, 115342.

Mahto, K. U., \& Das, S. (2020). Whole genome characterization and phenanthrene catabolic pathway of a biofilm forming marine bacterium Pseudomonas aeruginosa PFL-P1. Ecotoxicology and Environmental Safety, 206, 111087.

Mao, J., \& Guan, W. (2016). Fungal degradation of polycyclic aromatic hydrocarbons (PAHs) by Scopulariopsis brevicaulis and its application in bioremediation of PAH-contaminated soil. Acta Agriculturae Scandinavica, Section B -Soil \& Plant Science, 66(5), 399-405.

Moon, S. J., Kim, H. W., \& Jeon, S. J. (2018). Biochemical characterization of a thermostable cobalt-or copperdependent polyphenol oxidase with dye decolorizing ability from Geobacillus sp. JS12. Enzyme and microbial technology, 118, 30-36. 
Naghdi, M., Taheran, M., Brar, S. K., Kermanshahi-Pour, A., Verma, M., \& Surampalli, R. Y. (2018). Removal of pharmaceutical compounds in water and wastewater using fungal oxidoreductase enzymes. Environmental pollution, 234, 190-213.

Nguyen, V. H., Thi, L. A. P., Van Le, Q., Singh, P., Raizada, P., \& Kajitvichyanukul, P. (2020). Tailored photocatalysts and revealed reaction pathways for photodegradation of polycyclic aromatic hydrocarbons (PAHs) in water, soil and other sources. Chemosphere, 260, 127529.

Nowak, M., Zawadzka, K., \& Lisowska, K. (2020). Occurrence of methylisothiazolinone in water and soil samples in Poland and its biodegradation by Phanerochaete chrysosporium. Chemosphere, 254, 126723.

Park, H., Min, B., Jang, Y., Kim, J., Lipzen, A., Sharma, A., .. \& Choi, I. G. (2019). Comprehensive genomic and transcriptomic analysis of polycyclic aromatic hydrocarbon degradation by a mycoremediation fungus, Dentipellis sp. KUC8613. Applied microbiology and biotechnology, 103(19), 8145-8155.

Pourfadakari, S., Jorfi, S., Roudbari, A., Javid, A., Talebi, S. S., Ghadiri, S. K., \& Yousefi, N. (2020). Optimization of electro-kinetic process for remediation of soil contaminated with phenanthrene using response surface methodology. Environmental Science and Pollution Research, 1-12.

Pozdnyakova, N. N., Nikiforova, S. V., Makarov, O. E., Chernyshova, M. P., Pankin, K. E., Turkovskaya, O. V. (2010). Influence of cultivation conditions on pyrene degradation by the fungus Pleurotus ostreatus D1. World Journal of Microbiology and Biotechnology, 26, 205-211.

Pozdnyakova, N., Dubrovskaya, E., Chernyshova, M., Makarov, O., Golubev, S., Balandina, S., Turkovskaya, O. (2018). The degradation of three-ringed polycyclic aromatic hydrocarbons by wood-inhabiting fungus Pleurotus ostreatus and soil-inhabiting fungus Agaricus bisporus. Fungal biology, https://doi.org/10.1016/j.funbio.2018.02.007

Qian L, Chen B (2012). Enhanced oxidation of benzo[a]pyrene by crude enzyme extracts produced during interspecific fungal interaction of Trametes versicolor and Phanerochaete chrysosporium. J Environ Sci 24:1639-1646.

Romantschuk M, Sarand I, Petäinen T, Peltola R, Jonsson- Saraswathy A, Hallberg R. (2002). Degradation of pyrene by indigenous fungi from a former gasworks site. FEMS Microbiol Lett 210: 227-232.

Sack, U., T.M. Heinze, J. Deck, C.E. Cerniglia, R. Martens, F. Zadrazil, and W. Fritsche. 1997. Comparison of phenanthrene and pyrene degradation by different wood-decaying fungi. Appl. Environ. Microbiol. 63, 3919-3925.

Sandhu, D. K., Arora, D. S. (1985). Laccase production by Polyporus sanguineus under different nutritional and environmental conditions. Experientia, 41, 355-356.

Shafiei, M., Afzali, F., Karkhane, A. A., Ebrahimi, S. M., Haghbeen, K., \& Aminzadeh, S. (2019). Cohnella sp. A01 laccase: thermostable, detergent resistant, anti-environmental and industrial pollutants enzyme. Heliyon, 5(9), e02543.

Singh, H. (2006). Mycoremediation: fungal bioremediation. John Wiley and Sons.

Sutherland JB, Selby AL, Freeman JP, Evans FE, Cerniglia CE (1991) Metabolism of Phenanthrene by Phanerochaete chrysosporium. Appl Environ Microbiol 57:3310-3316. 
Tekere M, Mswaka AY, Zvauya R, Read JS (2001) Growth, dye degradation and ligninolytic activity studies on Zimbabwean white rot fungi. Enzyme Microb Technol 28:420-426.

Teng, Y., Luo, Y., Sun, M., Liu, Z., Li, Z., \& Christie, P. (2010). Effect of bioaugmentation by Paracoccus sp. strain HPD-2 on the soil microbial community and removal of polycyclic aromatic hydrocarbons from an aged contaminated soil. Bioresource Technology, 101(10), 3437-3443.

Ting, W. T. E., Yuan, S. Y., Wu, S. D., \& Chang, B. V. (2011). Biodegradation of phenanthrene and pyrene by Ganoderma lucidum. International Biodeterioration \& Biodegradation, 65(1), 238-242.

USEPA (US Environmental Protection Agency) (1988). Drinking water criteria document for polycyclic aromatic hydrocarbons (PAHs), Prepared by the Environmental Criteria and Assessment Office, Office of Health and Environmental Assessment, US Environmental Protection Agency, Cincinnati, $\mathrm{OH}$, for the office of drinking water. ECAOCIND010.

Wong, D. W. (2009). Structure and action mechanism of ligninolytic enzymes. Applied biochemistry and biotechnology, 157(2), 174-209.

Wu ML, Nie MQ, Wang XC, Su JM, Cao W (2010) Analysis of phenanthrene biodegradation by using FTIR, UV and GC-MS. Spectrochim Acta A 75:1047-1050.

Wu, M., Xu, Y., Ding, W., Li, Y., Xu, H. (2016). Mycoremediation of manganese and phenanthrene by Pleurotus eryngii mycelium enhanced by tween 80 and saponin. Applied Microbiology and Biotechnology, 100, 7249-7261.

Wulandari, R., Lotrakul, P., Punnapayak, H., Amirta, R., Kim, S. W., \& Prasongsuk, S. (2021). Toxicity evaluation and biodegradation of phenanthrene by laccase from Trametes polyzona PBURU 12. 3 Biotech, 11(1), 1-11.

Xu, Q., Huang, Z., Ji, S., Zhou, J., Shi, R., \& Shi, W. (2020). Cu 20 nanoparticles grafting onto PLA fibers via electron beam irradiation: bifunctional composite fibers with enhanced photocatalytic of organic pollutants in aqueous and soil systems. Journal of Radioanalytical and Nuclear Chemistry, 323(1), 253-261.

Xu, S. Y., Chen, Y. X., Wu, W. X., Wang, K. X., Lin, Q., Liang, X. Q (2006). Enhanced dissipation of phenanthrene and pyrene in spiked soils by combined plants cultivation. Science of the Total Environment, 363(1-3), 206-215.

Xu, Z., Wang, C., Li, H., Xu, S., Du, J., Chen, Y, Ma C \& Tang, J. (2021). Concentration, distribution, source apportionment, and risk assessment of surrounding soil PAHs in industrial and rural areas: A comparative study. Ecological Indicators, 125, 107513.

Yamanaka R, Soares CF, Matheus DR, Machado KMG (2008) Lignolytic enzymes produced by Trametes villosa CCB176 under different culture conditions. Braz J Microbiol 39:78-84.

Zebulum, H. O., Isikhuemhen, O. S., Inyang, H. (2011). Decontamination of anthracene-polluted soil through white rot fungus induced biodegradation. Environmentalist 31, 11-19.

Zhao HP, Wu QS, Wang L, Zhao XT, Gao HW (2009) Degradation of phenanthrene by bacterial strain isolated from soil in oil refinery fields in Shanghai China. J Hazard Mater 164(2):863-869.

Zhou, H., Zhang, S., Xie, J., Wei, H., Hu, Z., \& Wang, H. (2020). Pyrene biodegradation and its potential pathway involving Roseobacter clade bacteria. International Biodeterioration \& Biodegradation, 150, 104961. 


\section{Figures}
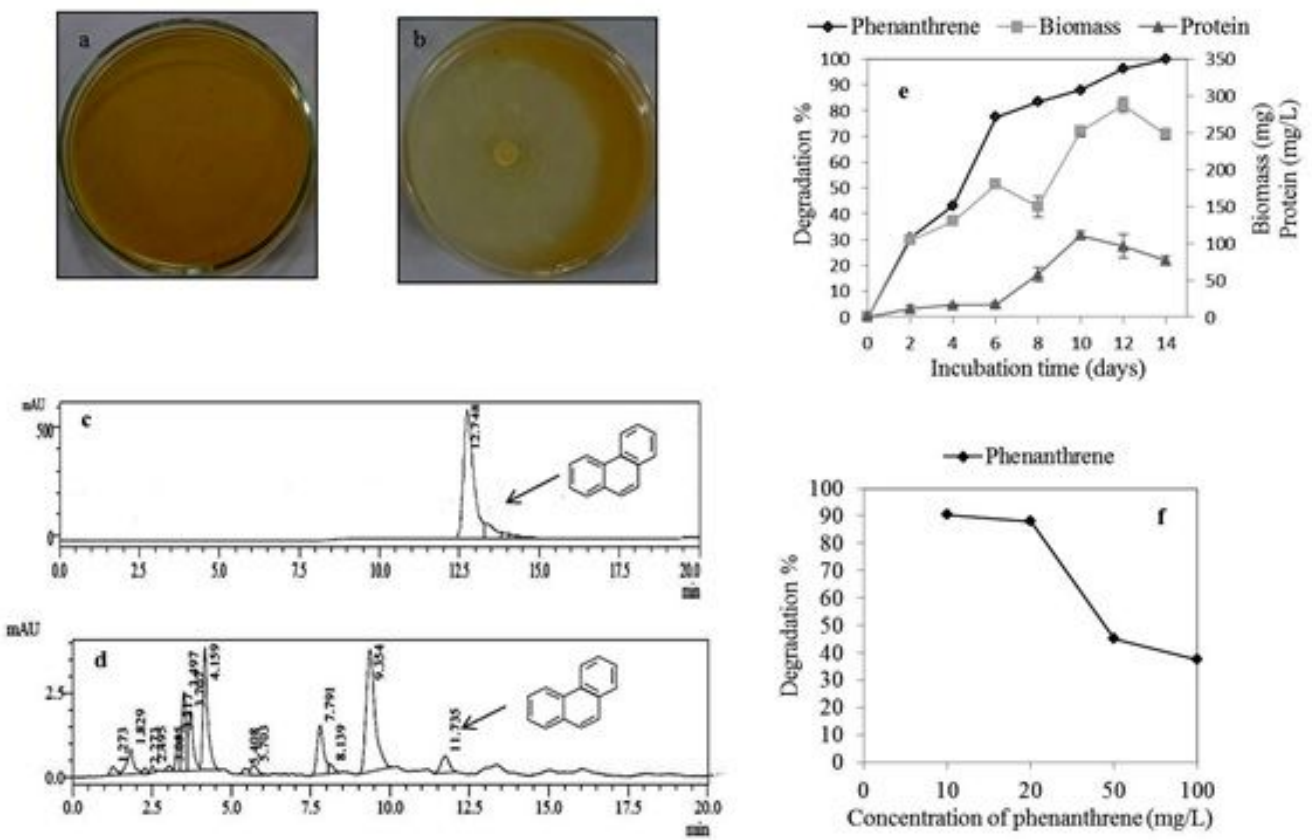

Figure 1

Qualitative analysis of PHE degradation, control (BHA media containing PHE) (a), Clear zone formation by strain APC5 after PHE degradation (b), Quantification of PHE degradation by HPLC chromatogram, chromatogram of PHE before (c) and after (d) treated by strain APC5, PHE degradation percentage and production of biomass, protein after degradation by strain APC5 (e), degradation of different concentration of PHE by strain APC5 (f). 

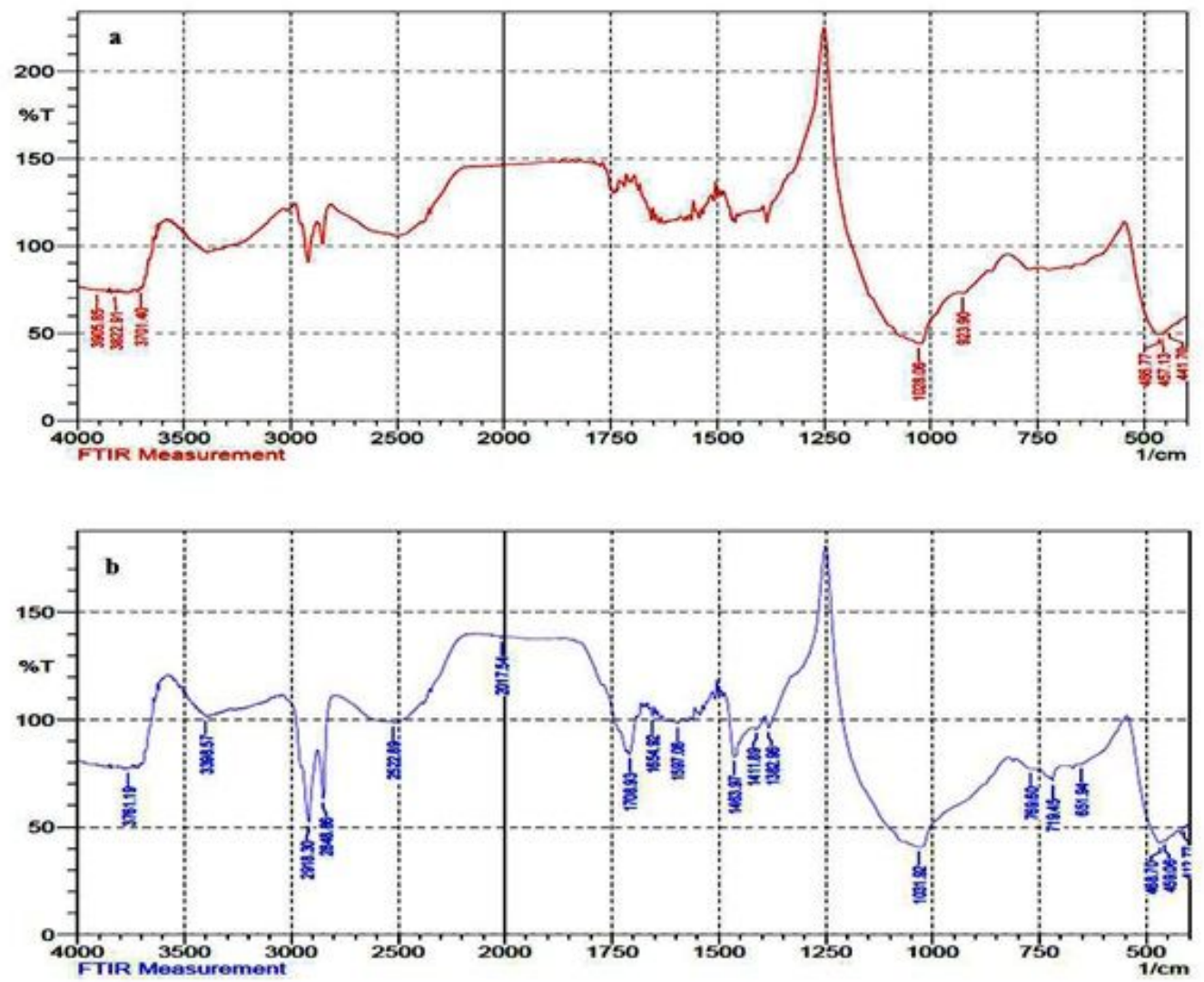

Figure 2

FTIR spectra of PHE before (a) and extracted metabolites (b) after PHE degradation by C. byrsina.
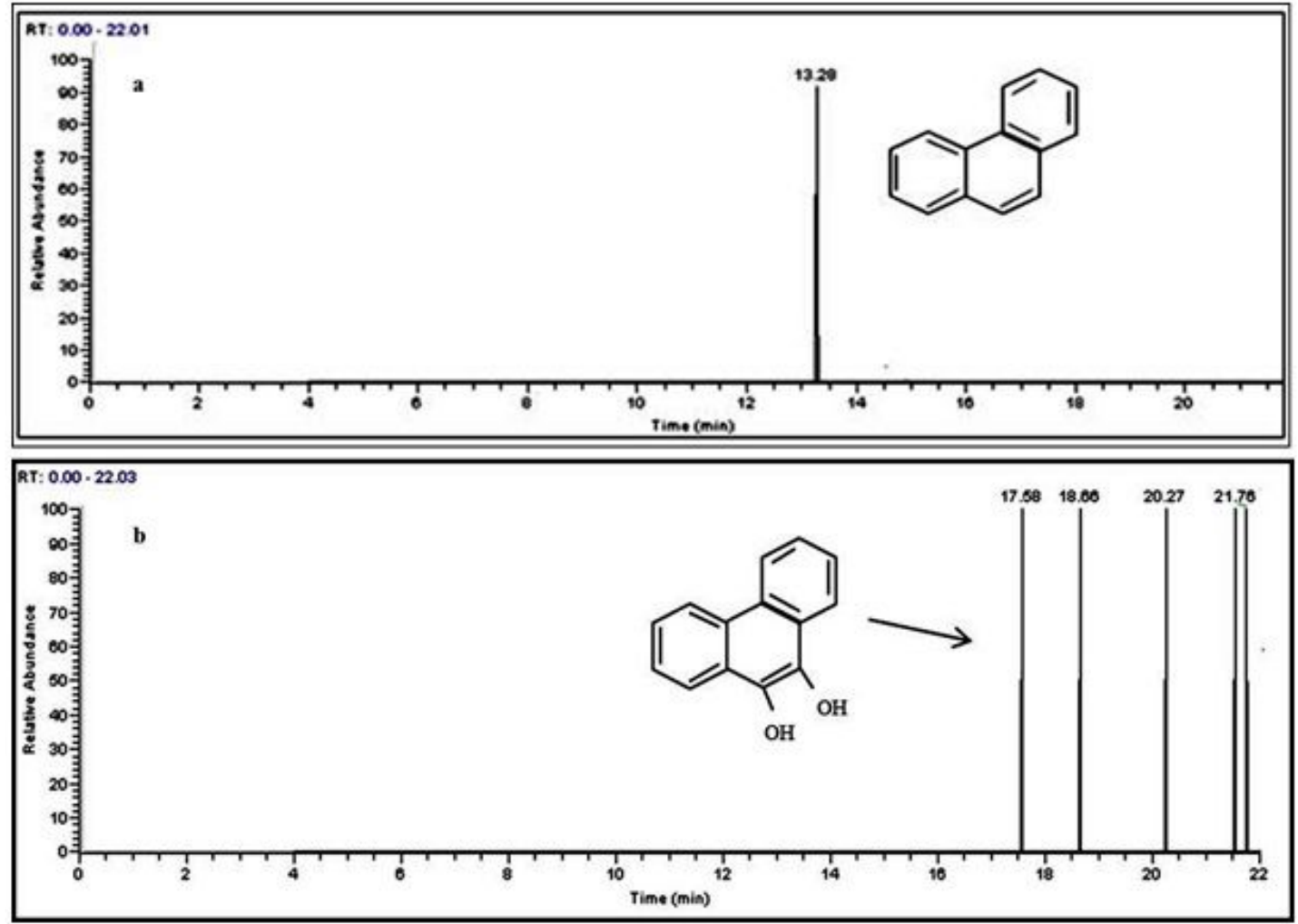
Figure 3

GC chromatogram of PHE (RT-13.28) before (a) and after 4th day (b), degradation by C. byrsina. Peak of 9, 10Dihydroxyphenanthrene (RT-17.58) (b) was detected by GC-MS library search.

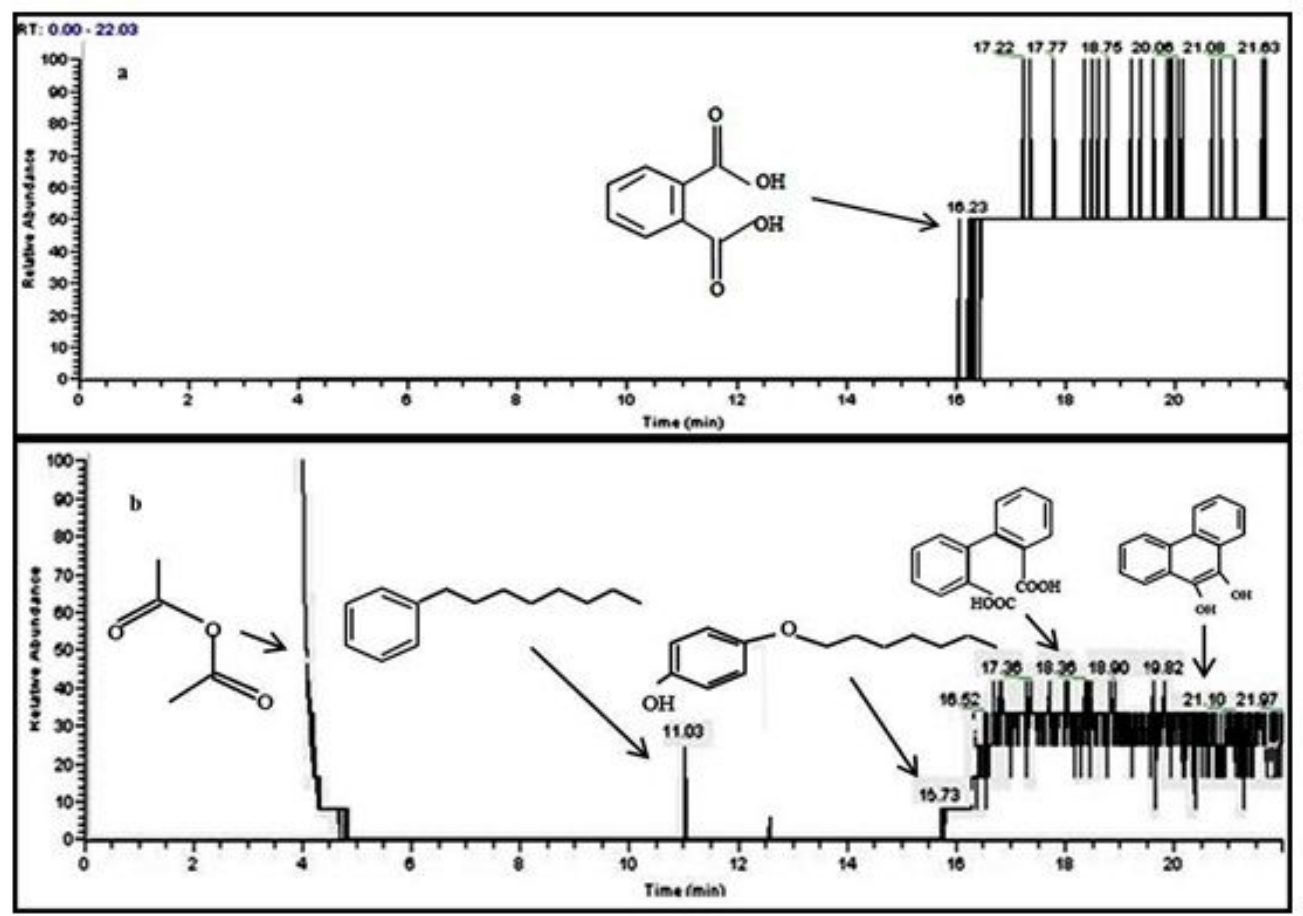

\section{Figure 4}

PHE degradation metabolites after 8th day (c), 12th day (d) of incubation by C. byrsina, Phthalic acid (RT-16.23) (c), and acetic acid anhydride (RT-4.05), benzene octyl (RT-11.03), 4-heptyloxy phenol (RT-15.73), 2, 2-Diphenic acid (RT18.36), 9, 10-Dihydroxyphenanthrene (RT-21.10) (d) were detected by GC-MS library search.

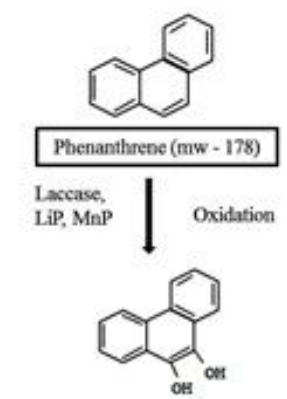

9, 10-Dihydroxyphenanthrene (nw - 210)

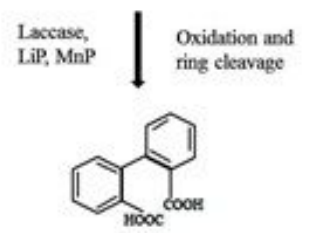

2, 2-Diphenic acid (mw - 242)

Laccase,

Oxidation and

L.iP, MnP

Oxidation and
ring cleavage
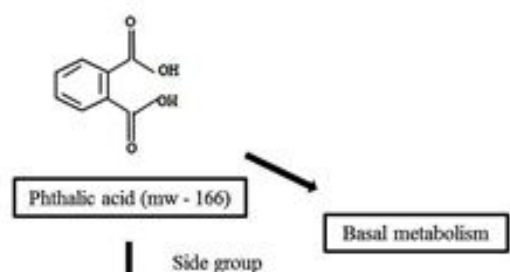

Side group
removal

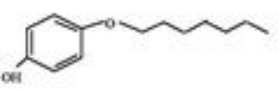

4- beptyloxy phenol (nw - 208)

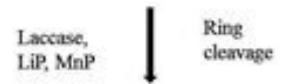

Non

Benzene octyl $(m w-190)$

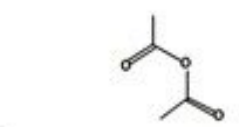

Acetic acid anhydride (mw - 102)

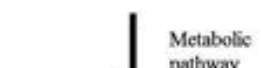
pathway

$\mathrm{CO}_{2}$

Carbon di oxide (nw - 44)

\section{Figure 5}


Proposed pathway of PHE degradation by C. byrsina on the basis of GCMS analysis.

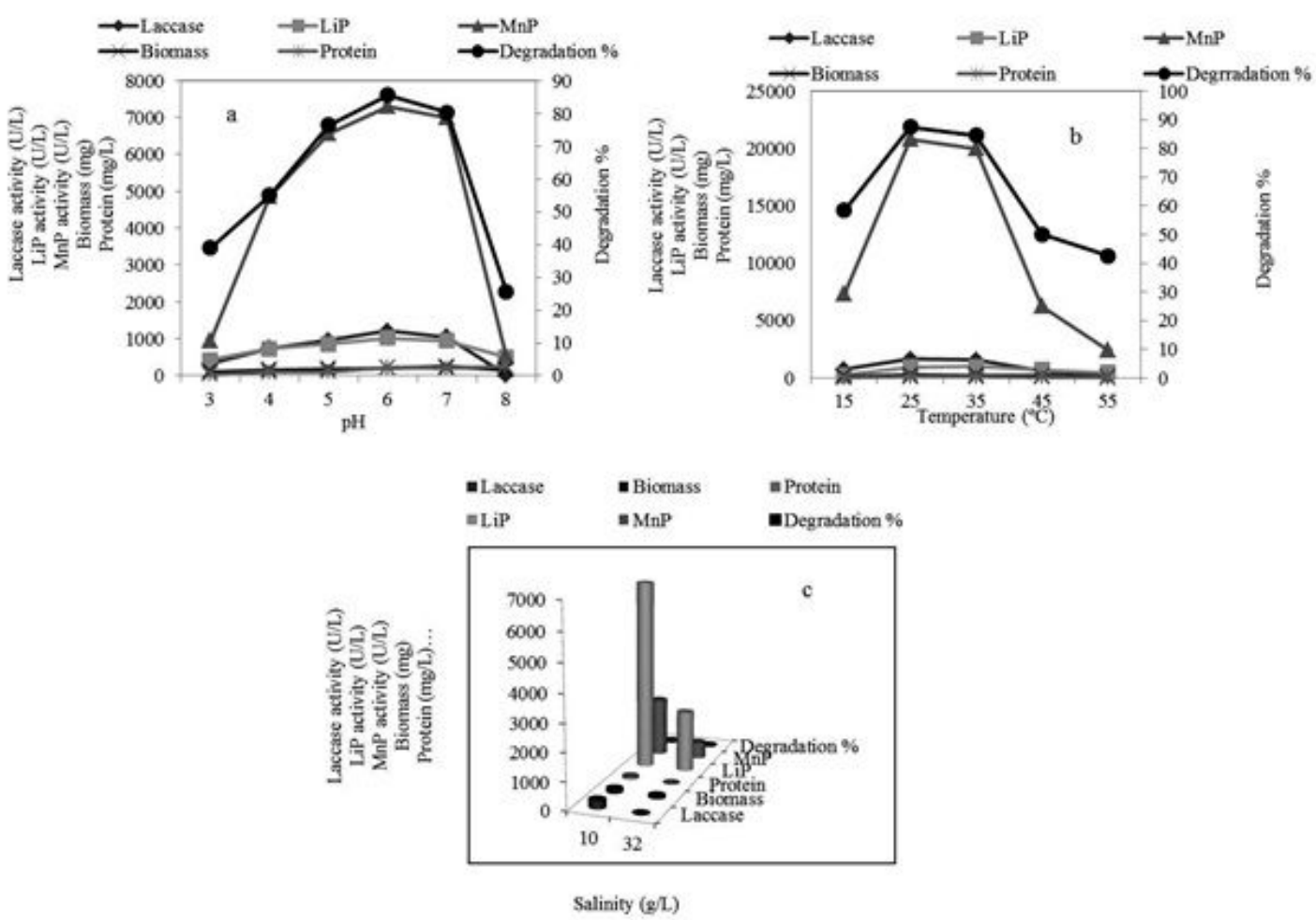

\section{Figure 6}

Degradation of PHE and ligninolytic enzyme production by C. byrsina under different $\mathrm{pH}(\mathrm{a})$, temperature (b) and saline condition (c). 


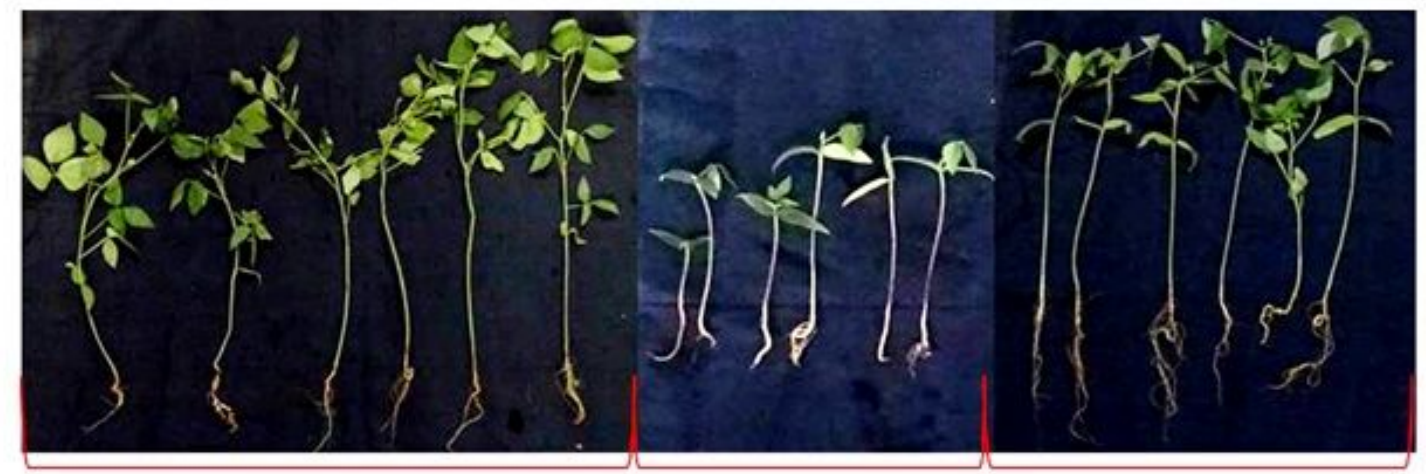

a Native soil

Phenanthrene contaminated soil

Bioremediated soil

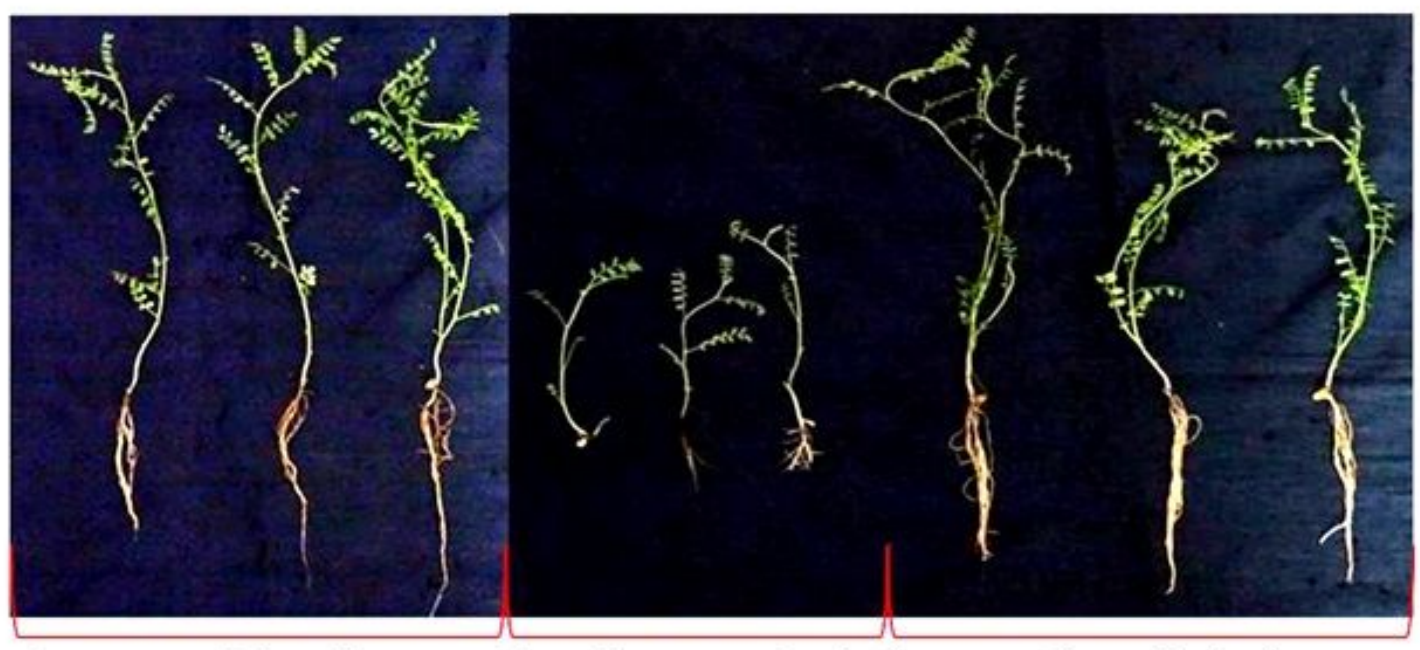

b Native soil

Phenanthrene contaminated soil

Bioremediated soil

\section{Figure 7}

The effect of PHE metabolites on the growth of Vigna radiata (a) and Cicer arietinum (b) growth cultivated in PHE degraded soil 